\title{
Current challenges in treatment options for visceral leishmaniasis in India: a public health perspective
}

\author{
Om Prakash Singh, Bhawana Singh, Jaya Chakravarty and Shyam Sundar
}

\begin{abstract}
Visceral leishmaniasis (VL) is a serious parasitic disease causing considerable mortality and major disability in the Indian subcontinent. It is most neglected tropical disease, particularly in terms of new drug development for the lack of financial returns. An elimination campaign has been running in India since 2005 that aim to reduce the incidence of VL to below 1 per 10,000 people at sub-district level. One of the major components in this endeavor is reducing transmission through early case detection followed by complete treatment. Substantial progress has been made during the recent years in the area of VL treatment, and the VL elimination initiatives have already saved many lives by deploying them effectively in the endemic areas. However, many challenges remain to be overcome including availability of drugs, cost of treatment (drugs and hospitalization), efficacy, adverse effects, and growing parasite resistance. Therefore, better emphasis on implementation research is urgently needed to determine how best to deliver existing interventions with available anti-leishmanial drugs. It is essential that the new treatment options become truly accessible, not simply available in endemic areas so that they may promote healing and save lives. In this review, we highlight the recent advancement and challenges in current treatment options for VL in disease endemic area, and discuss the possible strategies to improve the therapeutic outcome.
\end{abstract}

Keywords: Visceral leishmaniasis, Treatment, Drug resistance, Multidrug therapy

\section{Multilingual abstracts}

Please see Additional file 1 for translations of the abstract into the six official working languages of the United Nations.

\section{Introduction}

More than 1 billion people are affected by one or more neglected infectious diseases worldwide [1, 2], for which we lack effective, affordable, and easy to use drugs as well as other control methods. Visceral leishmaniasis (VL), also known as kala-azar, is one of the disorders in this group caused by a protozoan parasite, $L$. donovani and/or $L$. infantum, which is transmitted by the bite of an infected sand fly, Phlebotomus argentipes in the Indian subcontinent (ISC) [3]. VL results in prolonged fever, anemia, splenomegaly, wasting; and is fatal when left untreated [4]. There are approximately 200-400 thousands new cases every year

\footnotetext{
* Correspondence: drshyamsundar@hotmail.com

Infectious Disease Research Laboratory, Department of Medicine, Institute of Medical Sciences, Banaras Hindu University, Varanasi, India
}

occurring predominantly in just six countries: India, Bangladesh, Sudan, South Sudan, Ethiopia and Brazil [5]. More specifically, $>10,000$ cases occur in India alone every year and the state of Bihar accounts for majority of these cases. These figures, however, do not reflect the true social impact of this disease because VL has a focal distribution which is devastating to the affected communities. The cost of treatment is important when patients need to pay for treatment as $\sim 75 \%$ of the VL cases in Bihar live below the poverty threshold of less than US $\$ 1.0$ a day, and this is similar in other endemic countries although exact data are scarce [6]. Poverty seriously affects the prognosis of VL because most of the patients and their families have to pay for diagnosis, drugs and hospital care, and this is often half or more of the annual household income [7]. As a result, families with a VL infected member descend deeper into poverty.

VL has never been featured as high priority for drug development programs funded by the pharmaceutical industries because it disproportionately affects the poor 
people in developing countries and are unlikely to yield good returns on R\&D costs. In 2005, the governments of India, Bangladesh and Nepal signed a joint memorandum of understanding to eliminate VL with the aim to reduce the incidence to less than 1 per 10,000 people at sub-district level by the year 2015 [8] which has recently been extended to the year 2017 [9]. Because of the anthroponotic nature of the transmission of L.donovani in the ISC, the use of quality drugs is not only a therapeutic tool, but also a tool for VL control. Indeed, human beings are the only known reservoir of L.donovani, therefore, identification and proper treatment of parasite carriers will reduce the parasite biomass and prevents onward transmission and deaths (Fig. 1). These factors urge for search of new, effective, less toxic and simplified treatments to replace or complement the few currently available drugs. Unfortunately, no new antileishmanial drugs are expected in near future, because very few drugs are in the R\&D pipeline at various stages of development [10]. Furthermore, resistance to first line treatment has long plagued effective treatment of VL in India, making second line treatments and extended hospitalization more common. In India, about 5-10 \% of patients with VL, after recovery of acute illness, may develop a chronic cutaneous form called Post kala-azar dermal leishmaniasis (PKDL) that requires prolonged and expensive treatment [11]. The emergence of HIV and its association with VL results in a deadly synergy. A significant number of patients in Bihar are living with HIV-VL co-infection [12], and we expect to see more HIV-VL co-infections in near future which will further generate major therapeutic challenges [13]. In the following sections, we have briefly reviewed the current treatment of VL in endemic areas of Bihar, India, and discuss the challenges and its possible solutions.

\section{Treatment options for VL}

There is no vaccine available for VL; hence control of VL exclusively depends on chemotherapy. Available treatment options for VL are limited and not up to satisfactory standards due to problem relating to efficacy, adverse effects, increasing drug resistance, high cost and need for hospitalization to complete the full dose of treatment. So far, many clinical trials have been done in India to optimize the therapeutic regimens and to protect the efficacy of limited number of available anti-leishmanials (Tables 1 and 2). A full list of completed, ongoing and proposed clinical trials for leishmaniasis in various parts of the world is available on clinical trial registry site (https://clinicaltrials.gov). Indeed, important recent advances have been made in the area of VL treatment that if implemented effectively could eliminate this disease from most endemic parts of the world. Table 3 lists the rank wise recommended dose of anti-leishmanial drugs for VL treatment.

\section{Pentavalent Antimonials}

Past experiences have confirmed that response to a drug varies from region to region. For example, in hyperendemic regions of India and adjoining areas of Nepal, pentavalent antimonials $\left(\mathrm{Sb}^{\mathrm{v}}\right.$ also known as sodium stibogluconate) has lost its efficacy with the result that about two thirds of patients in some of these areas are refractory to $\mathrm{Sb}^{\mathrm{v}}$ treatment [14]. However, in Bangladesh, the situation is different as no resistance to $\mathrm{Sb}^{\mathrm{v}}$ has been officially reported. $\mathrm{Sb}^{\mathrm{V}}$ was recommended and used in Bangladesh till 2009 as a first line drug [15]. Moreover, $\mathrm{Sb}^{\mathrm{v}}$ are still the

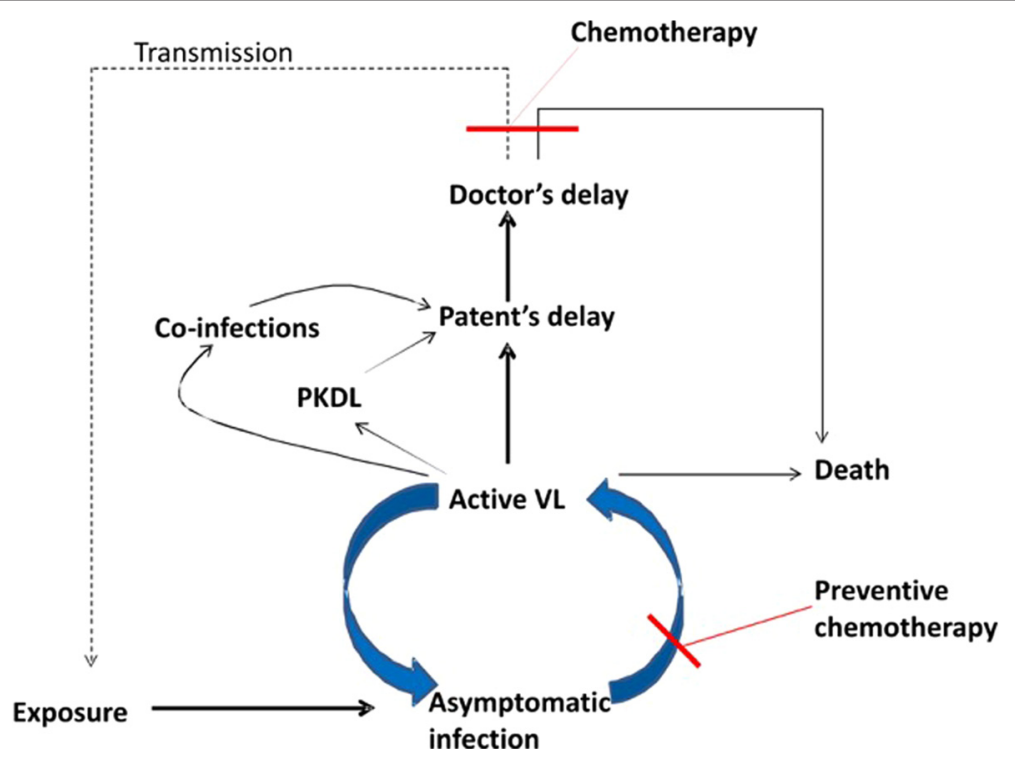

Fig. 1 Schematic of intervention model based on VL chemotherapy 
Table 1 Currently available anti-leishmanial drugs for treatment of VL: product name, cure rate, mode of action on parasite, advantages and limitations

\begin{tabular}{|c|c|c|c|c|c|c|}
\hline S.N. & Drugs & $\begin{array}{l}\text { Marketing authotization } \\
\text { and commercial } \\
\text { product }\end{array}$ & Cure rate & Mechanism of action & Advantages & Limitations \\
\hline \multirow[t]{2}{*}{1} & \multirow[t]{2}{*}{$\begin{array}{l}\text { Pentavalent } \\
\text { antimonials }\end{array}$} & \multirow{2}{*}{$\begin{array}{l}\text { Albert David, India } \\
\text { (generic SSG); } \\
\text { Wellcome (Pentostam); } \\
\text { Sanofi Aventis } \\
\text { (Glucantime) }\end{array}$} & \multirow{2}{*}{$\begin{array}{l}\text { 39-95\% } \\
\text { depending on } \\
\text { geographical } \\
\text { condition (50\% } \\
\text { in Bihar) }\end{array}$} & $\begin{array}{l}\text { Act as prodrug, inhibit trypanothione } \\
\text { reductase, increase the ROS }\end{array}$ & \multirow[t]{2}{*}{ Low cost and easy available } & \multirow{2}{*}{$\begin{array}{l}\text { Parasite resistance especially in India, } \\
\text { cardiotoxic, } 30 \text { day iv/im treatment in } \\
\text { hospital, painful injections }\end{array}$} \\
\hline & & & & $\begin{array}{l}\text { Inhibit macromolecular biosynthesis in } \\
\text { amastigotes }\end{array}$ & & \\
\hline \multirow[t]{2}{*}{2} & \multirow{2}{*}{$\begin{array}{l}\text { Amphotericin } \\
\text { B }\end{array}$} & Life care, India & \multirow{2}{*}{$\begin{array}{l}>98 \% \text { in all } \\
\text { regions }\end{array}$} & \multirow{2}{*}{$\begin{array}{l}\text { Form complexes with sterols mainly } \\
\text { ergosterols of parasite membrane } \\
\text { leading to increase permeability } \\
\text { resulting in cell death }\end{array}$} & \multirow{2}{*}{$\begin{array}{l}\text { High efficacy, } 1 \text { st line treatment } \\
\text { in case of antimonial resistance }\end{array}$} & \multirow{2}{*}{$\begin{array}{l}\text { Dose-limiting renal toxicity, } 15-30 \text { day slow } \\
\text { iv infusion treatment over } 4-6 \mathrm{~h} \text { in hospital, } \\
\text { hypokalaemia }\end{array}$} \\
\hline & & $\begin{array}{l}\text { (Fungitericin); Bristol - } \\
\text { Myers (Fungisone) }\end{array}$ & & & & \\
\hline \multirow[t]{5}{*}{3} & \multirow{5}{*}{$\begin{array}{l}\text { Liposomal } \\
\text { amphotericin } \\
\text { B }\end{array}$} & Gilead (AmBisome); & \multirow[t]{5}{*}{$>98 \%$} & \multirow{5}{*}{$\begin{array}{l}\text { Targeted delivery of drug to infected } \\
\text { macrophages and kill the parasites as } \\
\text { AmB }\end{array}$} & \multirow{5}{*}{$\begin{array}{l}\text { Highest therapeutic index of } \\
\text { available VL drugs, No need of } \\
\text { hospitalization, substantially less } \\
\text { nephro-toxic than AmB }\end{array}$} & \multirow{5}{*}{$\begin{array}{l}\text { Expensive, requirement of cool chain } \\
\text { temperature maintainance }\end{array}$} \\
\hline & & $\begin{array}{l}\text { Lifecare Innovation } \\
\text { (Fungisome); Bharat } \\
\text { Serum and Vaccine } \\
\text { (Amphomul); }\end{array}$ & & & & \\
\hline & & $\begin{array}{l}\text { Sequus Pharmaceuticals } \\
\text { (Amphocil); }\end{array}$ & & & & \\
\hline & & $\begin{array}{l}\text { ENZON } \\
\text { Pharmaceuticals } \\
\text { (Abelcet); }\end{array}$ & & & & \\
\hline & & $\begin{array}{l}\text { Lifecare Innovation } \\
\text { (Kalsome) }\end{array}$ & & & & \\
\hline 4 & Miltefosine & Paladin Labs (Impavido) & $94-97 \%$ & $\begin{array}{l}\text { Modulate cell surface receptors and } \\
\text { inositol metabolism of parasites, and cell } \\
\text { death is mediated by apoptosis, Inhibit } \\
\text { the cytochrome C oxidase }\end{array}$ & $\begin{array}{l}\text { Oral drug, Safe in HIV-VL } \\
\text { co-infection }\end{array}$ & $\begin{array}{l}\text { Teratogenic in experimental animals, originally } \\
\text { developed as an anti- cancer drug, expensive, Gl } \\
\text { toxicity, hepato- \& renaltoxicity in phase- } 4\end{array}$ \\
\hline 5 & Paromomycin & Gland Pharma/iOWH & $94 \%$ (India) & $\begin{array}{l}\text { Binds to } 305 \text { ribosomal subunit and } \\
\text { interfere with protein biosynthesis, } \\
\text { decrease the membrane potential of } \\
\text { parasite }\end{array}$ & Cheapest drug & $\begin{array}{l}\text { An aminoglycoside, therefore nephro- and ototoxicity } \\
\text { possible, but have not been reported in VL patients, } \\
\text { although reversible high tone audiometric shift may } \\
\text { occasionally occur during treatment }\end{array}$ \\
\hline 6 & Pentamidine & $\begin{array}{l}\text { Sanofi Aventis } \\
\text { (Pentacarinat) }\end{array}$ & $70-80 \%$ & $\begin{array}{l}\text { Inhibit mitochondrial topoisomerase II } \\
\text { and inhibit the transcription process }\end{array}$ & $\begin{array}{l}\text { Effective in combination } \\
\text { therapy }\end{array}$ & $\begin{array}{l}\text { Gastointestinal adverse effect, hypotension, } \\
\text { diabetes mellitus }\end{array}$ \\
\hline
\end{tabular}


Table 2 Summary of studies and clinical trials on monotherapy in treatment of visceral leishmaniasis in India

\begin{tabular}{|c|c|c|c|c|c|c|c|}
\hline Authors & Year & Drug & Type of study & $\begin{array}{l}\text { Patients } \\
(\mathrm{N})\end{array}$ & Treatment Scheme & Cure rate & Reference \\
\hline Thakur et al. & 1988 & $\begin{array}{l}\text { Pentavalent } \\
\text { antimonials }\end{array}$ & $\begin{array}{l}\text { Randomized dose } \\
\text { finding trial of SSG }\end{array}$ & 371 & $\begin{array}{l}20 \text { vs. } 10 \mathrm{mg} \mathrm{Sbv+/kg/day} \mathrm{for} \\
28 \text { days (i.m) }\end{array}$ & $60-100 \%$ & [108] \\
\hline Thakur et al. & 1991 & $\begin{array}{l}\text { Pentavalent } \\
\text { antimonials }\end{array}$ & Randomized trial & 312 & $\begin{array}{l}20 \text { mg Sbv+/kg/day for 20, } \\
30 \& 40 \text { days (i.m) }\end{array}$ & $71-94 \%$ & [109] \\
\hline Mishra et al. & 1991 & $\begin{array}{l}\text { Amphotericin B } \\
\text { deoxycholate }\end{array}$ & $\begin{array}{l}\text { Non-Comparative } \\
\text { study }\end{array}$ & 15 & $0.5 \mathrm{mg} / \mathrm{kg} /$ day for 28 days (i.v) & $93 \%$ & [110] \\
\hline \multirow[t]{2}{*}{ Mishra et al. } & \multirow[t]{2}{*}{1992} & \multirow{2}{*}{$\begin{array}{l}\text { Amphotericin B } \\
\text { deoxycholate vs. } \\
\text { Pentamidicine }\end{array}$} & \multirow{2}{*}{$\begin{array}{l}\text { Randomized } \\
\text { comparative study in } \\
\text { antimony } \\
\text { unresponsive } \\
\text { patients }\end{array}$} & \multirow[t]{2}{*}{120} & $\begin{array}{l}\text { AB: } 0.5 \mathrm{mg} / \mathrm{kg} / \mathrm{on} \text { alternate day } \\
\text { for } 14 \text { days (i.v) }\end{array}$ & \multirow[t]{2}{*}{$77-98 \%$} & \multirow[t]{2}{*}{ [111] } \\
\hline & & & & & $\begin{array}{l}\text { Pentamidinine: } 4 \mathrm{mg} / \mathrm{kg} \text { on alternate days } \\
\text { for } 20 \text { injections (i.m) }\end{array}$ & & \\
\hline Thakur et al. & 1993 & $\begin{array}{l}\text { Amphotericin B } \\
\text { deoxycholate }\end{array}$ & $\begin{array}{l}\text { Non comparative } \\
\text { study on SSG } \\
\text { resistant patients }\end{array}$ & 300 & $\begin{array}{l}1.0 \mathrm{mg} / \mathrm{kg} \text { on alternate day, } \\
\text { total dose } 20 \mathrm{mg} / \mathrm{kg} \text { (i.v) }\end{array}$ & $99 \%$ & [19] \\
\hline \multirow[t]{2}{*}{ Thakur et al. } & \multirow[t]{2}{*}{1993} & \multirow{2}{*}{$\begin{array}{l}\text { Amphotericin B } \\
\text { deoxycholate vs. } \\
\text { Pentavalent } \\
\text { antimonials }\end{array}$} & \multirow{2}{*}{$\begin{array}{l}\text { Randomized } \\
\text { controlled } \\
\text { comparative trial }\end{array}$} & \multirow[t]{2}{*}{150} & $\begin{array}{l}\text { AB: } 1.0 \mathrm{mg} / \mathrm{kg} \text { on alternate day, } \\
\text { total dose } 20 \mathrm{mg} / \mathrm{kg} \text { (i.v) }\end{array}$ & \multirow[t]{2}{*}{$80-100 \%$} & \multirow[t]{2}{*}{ [112] } \\
\hline & & & & & $\begin{array}{l}\text { SSG: } 20 \text { vs. } 10 \mathrm{mg} \mathrm{Sbv+/kg/day} \\
\text { for } 30 \text { days (i.m) }\end{array}$ & & \\
\hline \multirow[t]{2}{*}{ Mishra et al. } & \multirow[t]{2}{*}{1994} & \multirow{2}{*}{$\begin{array}{l}\text { Amphotericin B } \\
\text { deoxycholate vs. } \\
\text { Pentavalent } \\
\text { antimonials }\end{array}$} & \multirow{2}{*}{$\begin{array}{l}\text { Randomized } \\
\text { controlled } \\
\text { comparative trial }\end{array}$} & \multirow[t]{2}{*}{80} & $\begin{array}{l}\text { AB: } 0.5 \mathrm{mg} / \mathrm{kg} \text { on alternate day } \\
\text { for } 14 \text { days (i.v) }\end{array}$ & \multirow[t]{2}{*}{$62-100 \%$} & \multirow[t]{2}{*}{ [113] } \\
\hline & & & & & $\begin{array}{l}\text { SSG: } 20 \mathrm{mg} \mathrm{Sbv+/kg/day} \\
\text { for } 40 \text { days (i.m) }\end{array}$ & & \\
\hline Thakur et. al. & 1994 & $\begin{array}{l}\text { Amphotericin B } \\
\text { deoxycholate }\end{array}$ & $\begin{array}{l}\text { Radomized dose } \\
\text { finding study }\end{array}$ & 80 & $\begin{array}{l}1.0 \mathrm{mg} / \mathrm{kg} \text { on daily vs. alternate day, } \\
\text { total dose } 20 \mathrm{mg} / \mathrm{kg} \text { (i.v) }\end{array}$ & $100 \%$ & [114] \\
\hline Thakur et. al. & 1994 & $\begin{array}{l}\text { Amphotericin B } \\
\text { deoxycholate }\end{array}$ & Dose finding study & 120 & $\begin{array}{l}1.0 \mathrm{mg} / \mathrm{kg} / \text { day on incremental increasing dose } \\
\text { vs. contantdoase, total dose } 20 \mathrm{mg} / \mathrm{kg} \text { (i.v) }\end{array}$ & $100 \%$ & [115] \\
\hline Giri & 1994 & $\begin{array}{l}\text { Amphotericin B } \\
\text { deoxycholate }\end{array}$ & $\begin{array}{l}\text { Non comparative } \\
\text { study in } \\
\text { pentamidinde } \\
\text { relapse patients }\end{array}$ & 25 & $\begin{array}{l}0.75 \mathrm{mg} / \mathrm{kg} \text { on alternate days (i.v) } \\
\text { total } 15 \text { infusions }\end{array}$ & $100 \%$ & [116] \\
\hline Giri\& Singh & 1994 & $\begin{array}{l}\text { Amphotericin B } \\
\text { deoxycholate }\end{array}$ & $\begin{array}{l}\text { Non comparative } \\
\text { study in antimony } \\
\text { relapse patients }\end{array}$ & 100 & $\begin{array}{l}0.75 \mathrm{mg} / \mathrm{kg} \text { on alternate days (i.v) } \\
\text { total } 15 \text { infusions }\end{array}$ & $100 \%$ & [117] \\
\hline Jha et. al. & 1995 & $\begin{array}{l}\text { Amphotericin B } \\
\text { deoxycholate }\end{array}$ & $\begin{array}{l}\text { Dose finding study } \\
\text { in multidrug resistant } \\
\text { patients }\end{array}$ & 34 & $\begin{array}{l}1.0 \mathrm{mg} / \mathrm{kg} / \text { day on alternate days (i.v) } \\
\text { total } 10-15 \text { infusions }\end{array}$ & & [18] \\
\hline Thakur et.al. & 1996 & $\begin{array}{l}\text { Amphotericin B } \\
\text { deoxycholate }\end{array}$ & $\begin{array}{l}\text { Randomized dose } \\
\text { finding study }\end{array}$ & 288 & $\begin{array}{l}1.0 \mathrm{mg} \text { vs. } 0.75 \mathrm{mg} \text { vs. } 0.5 \mathrm{mg} / \mathrm{kg} / \text { day } \\
\text { for } 20 \text { days (i.v) }\end{array}$ & $79-99 \%$ & [118] \\
\hline Thakur et.al. & 1998 & $\begin{array}{l}\text { Amphotericin B } \\
\text { deoxycholate }\end{array}$ & $\begin{array}{l}\text { Randomized dose } \\
\text { finding study }\end{array}$ & 130 & $\begin{array}{l}1.0 \mathrm{mg} / \mathrm{kg} / \text { day for } 20 \text { days (i.v) vs. escalating } \\
\text { dose for } 5 \text { days then } 1.0 \mathrm{mg} / \mathrm{kg} / \text { day for } 43 \text { days }\end{array}$ & $99 \%$ & [119] \\
\hline Thakur et.al. & 1999 & $\begin{array}{l}\text { Amphotericin B } \\
\text { deoxycholate }\end{array}$ & $\begin{array}{l}\text { Non comparative } \\
\text { dose finding study }\end{array}$ & 938 & $1.0 \mathrm{mg} / \mathrm{kg} /$ day for 20 days (i.v) & $99.2 \%$ & [120] \\
\hline $\begin{array}{l}\text { Thakur \& } \\
\text { Ahmed }\end{array}$ & 2001 & $\begin{array}{l}\text { Amphotericin B } \\
\text { deoxycholate }\end{array}$ & $\begin{array}{l}\text { Non comparative } \\
\text { study }\end{array}$ & 309 & $1.0 \mathrm{mg} / \mathrm{kg} /$ day for 20 days (i.v) & $95.8 \%$ & [22] \\
\hline \multirow{2}{*}{$\begin{array}{l}\text { Thakur \& } \\
\text { Narayan }\end{array}$} & \multirow[t]{2}{*}{2004} & \multirow{2}{*}{$\begin{array}{l}\text { Amphotericin B } \\
\text { deoxycholate vs. } \\
\text { SSG }\end{array}$} & \multirow{2}{*}{$\begin{array}{l}\text { Randomized } \\
\text { comparative study }\end{array}$} & \multirow[t]{2}{*}{60} & AB: $1.0 \mathrm{mg} / \mathrm{kg} /$ day for 20 days (i.v) & \multirow{2}{*}{$\begin{array}{l}46.6 \text { and } \\
100 \%\end{array}$} & \multirow[t]{2}{*}{ [121] } \\
\hline & & & & & $\begin{array}{l}\text { SSG: } 20 \text { vs. } 10 \mathrm{mg} \mathrm{Sbv+/kg/day} \\
\text { for } 28 \text { days (i.m) }\end{array}$ & & \\
\hline Singh et.al. & 2010 & $\begin{array}{l}\text { Amphotericin B } \\
\text { deoxycholate }\end{array}$ & $\begin{array}{l}\text { Randomized study in } \\
\text { children's }\end{array}$ & 605 & $\begin{array}{l}1.0 \mathrm{mg} / \mathrm{kg} / \text { day for } 15 \text { days daily vs. } \\
\text { alternate days (i.v) }\end{array}$ & $100 \%$ & [122] \\
\hline Thakur et.al. & 1996 & $\begin{array}{l}\text { Liposomal } \\
\text { Amphotericin B } \\
\text { (LAB) }\end{array}$ & $\begin{array}{l}\text { Randomized open } \\
\text { study of different } \\
\text { schedule }\end{array}$ & 30 & $\begin{array}{l}2 \mathrm{mg} / \mathrm{kg} / \text { day on day } 1,2,3,4,5,6 \text { and } 10 \\
\text { vs. days } 1,2,3,4 \text { and } 10\end{array}$ & $100 \%$ & [123] \\
\hline \multirow[t]{2}{*}{ Thakur et.al. } & \multirow[t]{2}{*}{2001} & \multirow{2}{*}{$\begin{array}{l}\text { Liposomal } \\
\text { Amphotericin B vs. }\end{array}$} & \multirow[t]{2}{*}{ Randomized trial } & 34 & LAB: 15 mg/kg single dose (i.v) & $100 \%$ & {$[28]$} \\
\hline & & & & & AB: $1.0 \mathrm{mg} / \mathrm{kg} /$ day for 20 days (i.v) & & \\
\hline
\end{tabular}


Table 2 Summary of studies and clinical trials on monotherapy in treatment of visceral leishmaniasis in India (Continued)

\begin{tabular}{|c|c|c|c|c|c|c|c|}
\hline & & $\begin{array}{l}\text { Amphotericin B } \\
\text { deoxycholate }\end{array}$ & & & & & \\
\hline Sundar et.al. & 2001 & $\begin{array}{l}\text { Liposomal } \\
\text { Amphotericin B }\end{array}$ & $\begin{array}{l}\text { Open label dose } \\
\text { finding study }\end{array}$ & 91 & $\begin{array}{l}5 \mathrm{mg} / \mathrm{kg} \text { (single dose) vs. } 1 \mathrm{mg} / \mathrm{kg} \text { for } \\
5 \text { days (iv) }\end{array}$ & $\begin{array}{l}91 \text { and } \\
93 \%\end{array}$ & {$[30]$} \\
\hline \multirow[t]{5}{*}{ Sundar et.al. } & \multirow[t]{5}{*}{2002} & \multirow{5}{*}{$\begin{array}{l}\text { Liposomal } \\
\text { Amphotericin B }\end{array}$} & \multirow{5}{*}{$\begin{array}{l}\text { Randomized double- } \\
\text { blind dose ranging } \\
\text { multicentre trial }\end{array}$} & \multirow[t]{5}{*}{84} & 0.75 mg/kg/days for 5 days (i.v) & \multirow{5}{*}{$\begin{array}{l}89,93 \text { and } \\
96 \%\end{array}$} & \multirow[t]{5}{*}{ [124] } \\
\hline & & & & & Vs & & \\
\hline & & & & & 1.5 mg/kg/days for 5 days (i.v) & & \\
\hline & & & & & Vs & & \\
\hline & & & & & $3.0 \mathrm{mg} / \mathrm{kg} /$ days for 5 days (i.v) & & \\
\hline Sundar et.al. & 2003 & $\begin{array}{l}\text { Liposomal } \\
\text { Amphotericin B }\end{array}$ & $\begin{array}{l}\text { Open label non } \\
\text { comparative study }\end{array}$ & 203 & $5.0 \mathrm{mg} / \mathrm{kg} /$ days for 5 days (i.v) & $90 \%$ & {$[29]$} \\
\hline Sundar et.al. & 2004 & $\begin{array}{l}\text { Liposomal } \\
\text { Amphotericin B vs. } \\
\text { Amphotericin B } \\
\text { deoxycholate }\end{array}$ & $\begin{array}{l}\text { Randomized } \\
\text { comparative study }\end{array}$ & 153 & $\begin{array}{l}\text { AB: } 1.0 \mathrm{mg} / \mathrm{kg} / \text { day for } 15 \text { dose on alternate } \\
\text { days (i.v); LAB: } 2.0 \mathrm{mg} / \mathrm{kg} / \text { day for } 5 \text { days (i.v) Vs. } \\
\text { Amphotericin B lipid complex } 2 \mathrm{mg} / \mathrm{kg} / \text { day for } \\
5 \text { days (i.v) }\end{array}$ & $\begin{array}{l}96,96 \text { and } \\
92 \%\end{array}$ & [125] \\
\hline Sinha et.al. & 2010 & $\begin{array}{l}\text { Liposomal } \\
\text { Amphotericin B }\end{array}$ & $\begin{array}{l}\text { Observational cohort } \\
\text { study }\end{array}$ & 251 & $5.0 \mathrm{mg} / \mathrm{kg} /$ day (i.v) on $0,1,4$, and 9 & $98.8 \%$ & [126] \\
\hline \multirow[t]{2}{*}{ Sundar et.al. } & \multirow[t]{2}{*}{2010} & \multirow{2}{*}{$\begin{array}{l}\text { Liposomal } \\
\text { Amphotericin B vs. } \\
\text { Amphotericin B } \\
\text { deoxycholate }\end{array}$} & \multirow{2}{*}{$\begin{array}{l}\text { Open label } \\
\text { randomized } \\
\text { controlled non } \\
\text { inferiority study }\end{array}$} & \multirow[t]{2}{*}{412} & LAB: 10.0 mg/kg/day (i.v) single dose & \multirow{2}{*}{$\begin{array}{l}95.7 \text { and } \\
96.3 \%\end{array}$} & \multirow[t]{2}{*}[27]{} \\
\hline & & & & & AB: 1.0 mg/kg/day for 15 alternate dose (i.v) & & \\
\hline Thakur et.al. & 1984 & Pentamidine & $\begin{array}{l}\text { Non-comparative } \\
\text { study in SSG } \\
\text { unresponsive } \\
\text { patients }\end{array}$ & 86 & $\begin{array}{l}4 \mathrm{mg} / \mathrm{kg} /(\mathrm{i} . \mathrm{m} \text { ) for } 15 \text { dose } \\
\text { (total dose } 60 \mathrm{mg} / \mathrm{kg} \text { ) }\end{array}$ & $93.4 \%$ & [127] \\
\hline \multirow[t]{3}{*}{ Thakur et.al. } & \multirow[t]{3}{*}{1991} & \multirow[t]{3}{*}{ Pentamidine } & \multirow{3}{*}{$\begin{array}{l}\text { Randomized } \\
\text { controlled } \\
\text { comparative study }\end{array}$} & \multirow[t]{3}{*}{312} & Group1: 4 mg/kg (i.v) 3 times weekly & \multirow{3}{*}{$\begin{array}{l}78,84 \text { and } \\
98 \% \\
\text { respectively }\end{array}$} & \multirow[t]{3}{*}{ [128] } \\
\hline & & & & & $\begin{array}{l}\text { Group2: } 4 \text { mg/kg (i.v) } 3 \text { times weekly + SSG } 20 \\
\text { mgSbv+/kg (i.m) daily for } 20 \text { days }\end{array}$ & & \\
\hline & & & & & $\begin{array}{l}\text { Group3: } 4 \text { mg/kg (i.v) } 3 \text { times weekly until } \\
\text { spleen were free from parasite + SSG } 20 \text { mgSbv } \\
\text { +/kg (i.m) daily for } 20 \text { days }\end{array}$ & & \\
\hline \multirow[t]{2}{*}{ Mishra et.al. } & \multirow[t]{2}{*}{1992} & \multirow[t]{2}{*}{ Pentamidine } & \multirow{2}{*}{$\begin{array}{l}\text { Randomized } \\
\text { controlled } \\
\text { comparative study }\end{array}$} & \multirow[t]{2}{*}{120} & $\begin{array}{l}\text { Pentamidine: } 4 \mathrm{mg} / \mathrm{kg} \text { (i.m) on alternate days } \\
\text { (total } 20 \text { dose) }\end{array}$ & \multirow[t]{2}{*}{$\begin{array}{l}77 \text { and } \\
98 \%\end{array}$} & \multirow[t]{2}{*}{ [111] } \\
\hline & & & & & AB: 0.5 mg.kg (i.v) on alternate days & & \\
\hline \multirow[t]{2}{*}{ Das et.al. } & \multirow[t]{2}{*}{2001} & Pentamidine & $\begin{array}{l}\text { Randomized } \\
\text { controlled } \\
\text { comparative study }\end{array}$ & 158 & $\begin{array}{l}\text { Group } 1: 2 \mathrm{mg} / \mathrm{kg} / \text { day (i.m) on alternate days + } \\
\text { oral allopurinol } 15 \mathrm{mg} / \mathrm{kg} / \text { day in } 3 \text { divided dose } \\
\text { for } 30 \text { days }\end{array}$ & $\begin{array}{l}91.2 \text { and } \\
74.3 \%\end{array}$ & {$[67]$} \\
\hline & & & & & $\begin{array}{l}\text { Group } 2: 4 \mathrm{mg} / \mathrm{kg} / \text { day (i.m) on alternate days } \\
\text { for } 30 \text { days }\end{array}$ & & \\
\hline Das et.al. & 2009 & Pentamidine & $\begin{array}{l}\text { Randomized } \\
\text { controlled }\end{array}$ & 82 & $\begin{array}{l}\text { Group 1: AB- } 1 \text { mg/kg/day alternate days for } \\
15 \text { days (i.v) }\end{array}$ & $\begin{array}{l}92 \text { and } \\
73 \%\end{array}$ & [129] \\
\hline & & & & & $\begin{array}{l}\text { Group 2: Pentamidine- } 4 \text { mg/kg/day alternate } \\
\text { days (i.m) }\end{array}$ & & \\
\hline Jha et.al. & 1998 & Paromomycin & Randomized & 120 & Group1: 12 mg/kg/day for 21 days (i.m) & 76.7, 96.7, & [130] \\
\hline & & & $\begin{array}{l}\text { controlled } \\
\text { comparative study }\end{array}$ & & Group 2: 16 mg/kg/day for 21 days (i.m) & $\begin{array}{l}96.1, \text { and } \\
63.3 \%\end{array}$ & \\
\hline & & & & & Group 3: 20 mg/kg/day for 21 days (i.m) & & \\
\hline & & & & & $\begin{array}{l}\text { Group 4: SSG } 20 \text { mg Sbv+/kg/day for } 30 \text { days } \\
\text { (i.m) }\end{array}$ & & \\
\hline Sunder et.al. & 2007 & Paromomycin & $\begin{array}{l}\text { Randomized } \\
\text { controlled phase III }\end{array}$ & 667 & $\begin{array}{l}\text { Group } 1 \text { : Parmomycin } 11 \text { mg/kg/day for } \\
21 \text { days (i.m) }\end{array}$ & $\begin{array}{l}94.6 \text { and } \\
98.8 \%\end{array}$ & {$[49]$} \\
\hline & & & $\begin{array}{l}\text { open label } \\
\text { comparative study }\end{array}$ & & Group 2 : AB 1 mg/kg/day for 30 days (i.v) & & \\
\hline Sunder et.al. & 2009 & Paromomycin & Randomized open & 329 & Group $1: 11$ mg/kg/day for 14 days (i.m) & $82-92.8 \%$ & [131] \\
\hline & & & & & Group 2: $11 \mathrm{mg} / \mathrm{kg} /$ day for 21 days (i.v) & & \\
\hline
\end{tabular}


Table 2 Summary of studies and clinical trials on monotherapy in treatment of visceral leishmaniasis in India (Continued)

\begin{tabular}{|c|c|c|c|c|c|c|c|}
\hline Sinha et.al. & 2011 & Paromomycin & $\begin{array}{l}\text { Phase IV open label } \\
\text { study }\end{array}$ & 506 & 11 mg/kg/day for 21 days (i.m) & $94.2 \%$ & [132] \\
\hline Sundar et al. & 1998 & Miltefosine & $\begin{array}{l}\text { Phase-l/II safety and } \\
\text { efficacy trial }\end{array}$ & 30 & $50 \mathrm{mg}-250 \mathrm{mg} /$ day for 28 days (oral) & $20-100 \%$ & [133] \\
\hline Jha et al. & 1999 & Miltefosine & $\begin{array}{l}\text { Phase } \| \text { randomized } \\
\text { open label, dose } \\
\text { finding }\end{array}$ & 120 & $\begin{array}{l}50 \mathrm{mg} / \text { day for } 6 \text { weeks; } 50 \mathrm{mg} / \text { day for } 1 \text { week } \\
\text { followed by } 150 \mathrm{mg} / \text { day for } 3 \text { week; } 100 \mathrm{mg} / \\
\text { day for } 4 \text { week; } 100 \mathrm{mg} / \text { day for } 1 \text { week } \\
\text { followed by } 150 \mathrm{mg} / \text { day for } 3 \text { week }\end{array}$ & $93-97 \%$ & [134] \\
\hline Sundar et al. & 1999 & Miltefosine & $\begin{array}{l}\text { Phase II comparative } \\
\text { clinical trial }\end{array}$ & 45 & 100-200 mg/day for 28 days & $94-100 \%$ & [135] \\
\hline Sundar et al. & 2000 & Miltefosine & $\begin{array}{l}\text { Phase II, Comparative } \\
\text { study }\end{array}$ & 54 & $100 \mathrm{mg} /$ day for 14 days, 21 days or 28 days & $88-100 \%$ & [136] \\
\hline \multirow[t]{2}{*}{ Sundar et al. } & \multirow[t]{2}{*}{2002} & \multirow[t]{2}{*}{ Miltefosine } & \multirow{2}{*}{$\begin{array}{l}\text { Randomized open } \\
\text { label comparative } \\
\text { study }\end{array}$} & \multirow[t]{2}{*}{398} & Miltefosine: 50-100 mg/day for 28 days & \multirow[t]{2}{*}{$97-100 \%$} & \multirow[t]{2}{*}{ [58] } \\
\hline & & & & & AmB:1 mg/kg/day (i.v) for 15 days & & \\
\hline Sundar et al. & 2003 & Miltefosine & $\begin{array}{l}\text { Open label phase ॥ } \\
\text { dose ranging study } \\
\text { in childrens }\end{array}$ & 39 & 1.5 or $2.5 \mathrm{mg} / \mathrm{kg} /$ day for 28 days & $88-90 \%$ & [137] \\
\hline $\begin{array}{l}\text { Bhataacharya } \\
\text { et al. }\end{array}$ & 2004 & Miletfosine & $\begin{array}{l}\text { Phase II trial in } \\
\text { childrens }\end{array}$ & 80 & $2.5 \mathrm{mg} / \mathrm{kg} /$ day for 28 days & $94 \%$ & [138] \\
\hline \multirow[t]{2}{*}{ Singh et al. } & \multirow[t]{2}{*}{2006} & \multirow[t]{2}{*}{ Miltefosine } & \multirow{2}{*}{$\begin{array}{l}\text { Prospective } \\
\text { multicentric cross } \\
\text { sectional study }\end{array}$} & \multirow[t]{2}{*}{125} & Miltefosine: $2.5-100 \mathrm{mg} / \mathrm{kg} /$ day for 28 days & \multirow{2}{*}{$\begin{array}{l}91.3- \\
93.2 \%\end{array}$} & \multirow[t]{2}{*}{ [139] } \\
\hline & & & & & AmB: $1 \mathrm{mg} / \mathrm{kg} /$ day (i.v) for 15 days & & \\
\hline $\begin{array}{l}\text { Bhattacharya } \\
\text { et al. }\end{array}$ & 2007 & Miltefosine & $\begin{array}{l}\text { Phase IV open label } \\
\text { single arm trial }\end{array}$ & 2109 & $2.5-100 \mathrm{mg} / \mathrm{kg} / \mathrm{day}$ for 28 days & $\begin{array}{l}93.6- \\
96.6 \%\end{array}$ & [140] \\
\hline Sundar et al. & 2012 & Miltefosine & $\begin{array}{l}\text { Open label } \\
\text { comparative study }\end{array}$ & 567 & $50-100 \mathrm{mg} / \mathrm{kg} /$ day for 28 days & $90.3 \%$ & {$[61]$} \\
\hline
\end{tabular}

first-line drugs in many countries worldwide for all clinical forms. Major side effects are cardiac arrhythmias, prolonged QT interval, ventricular premature beats, ventricular tachycardia and ventricular fibrillation [16]. There are accumulating evidence suggesting that $\mathrm{Sb}^{\mathrm{v}}$ has a dual mode of action, and acts on both the parasite and the infected macrophage. Upon contact with infected macrophages, $\mathrm{Sb}^{\mathrm{v}}$ stimulates the macrophages to kill the intracellular parasites and when reaching the parasite, $\mathrm{Sb}^{\mathrm{v}}$ is reduced to $\mathrm{Sb}^{\mathrm{III}}$, which can directly kill the parasite inside phagolysosome by inhibiting trypanothoine reductase (an enzyme that recycle oxidized trypanothione to keep the trypanothione in reducing state) [17]. Pentamidine, a diamidine compound, was the first drug to be used in $\mathrm{Sb}^{\mathrm{v}}$ refractory patients, and cured most patients initially, but after a decade its efficacy also declined from 100 to $70 \%$ in hyper-endemic areas of India.

\section{Amphotericin B Dexoycholate (AmB)}

Amphotericin $B(A m B)$ was initially recommended in India for treatment of patient's refractory to $\mathrm{Sb}^{\mathrm{v}}[18,19]$. However, due to increasing unresponsiveness of $\mathrm{Sb}^{\mathrm{v}}$ in endemic areas, it is currently being used as first line drug for VL treatment. AmB formulated with sodium deoxycholate was the first parenteral amphotericin B preparation available commercially as Fungizone (Bristol-Meyer-Squibb). Several clinical trials have been conducted till date for treatment of
VL involving AmB (reviewed in ref.[20, 21]) with excellent cure rate $(\sim 100 \%)$ at dose of $0.75-1.0 \mathrm{mg} / \mathrm{kg}$ for $15-20$ intravenous infusions [22, 23]. The drug has high safety and efficacy; however, prolonged hospitalization, adverse reactions like high fever with rigor and chills, and the need to close monitoring of renal functions and electrolyte levels are well-recognized drawbacks of AmB treatment (Table 2 enlists the studies in India with AmB). The mechanism of action of AmB is still not fully investigated but it is assumed that it interferes with the ergosterol in the cell membrane of Leishmania parasite, causing changes in the membrane permeability and leakage of intracellular components [24]. Cell death occurs in part because of these permeability changes, but other mechanisms may also contribute to $\mathrm{AmB}$ antifungal activity. $\mathrm{AmB}$ is not active in vitro against organisms that do not contain sterols in their cell membranes (e.g., bacteria). Binding to sterols in mammalian cells (e.g., certain kidney cells, erythrocytes) may be responsible for the toxicities associated with AmB (reviewed in ref. [25]).

\section{Lipid formulations of Amphotericin B (L-AmB)}

The advent of Liposome Technology in mid 1960s and subsequently its application for minimizing dose-limiting toxicity has added a new paradigm in AmB treatment, providing a highly effective and safe therapy for many forms of systemic mycosis. There are six lipid formulations of 
Table 3 Recommended treatment regimens for $V L$ in Indian subcontinent (ranked by preferences)

Anthroponotic VL caused by L.donovani in India, Bangladesh, Bhutan and Nepal

1. Liposomal amphotericin B: $3-5 \mathrm{mg} / \mathrm{kg}$ per daily dose by infusion given over 3-5-day period up to a total dose of $15 \mathrm{mg} / \mathrm{kg}$ (A) by infusion or $10 \mathrm{mg} / \mathrm{kg}$ as a single dose by infusion (A).

2. Combinations (co-administered) (A)

- liposomal amphotericin B (5 mg/kg by infusion, single dose) plus miltefosine (daily for 7 days, as below)

- liposomal amphotericin B ( $5 \mathrm{mg} / \mathrm{kg}$ by infusion, single dose) plus paromomycin (daily for 10 days, as below)

- miltefosine plus paromomycin, both daily for 10 days, as below.

3. Amphotericin B deoxycholate: $0.75-1.0 \mathrm{mg} / \mathrm{kg}$ per day by infusion, daily or on alternate days for 15-20 doses (A).

4. Miltefosine: for children aged 2-11 years, $2.5 \mathrm{mg} / \mathrm{kg}$ per day; for people aged $\geq 12$ years and $<25 \mathrm{~kg}$ body weight, $50 \mathrm{mg} /$ day; $25-50 \mathrm{~kg}$ body weight, $100 \mathrm{mg} / \mathrm{day}$; $>50 \mathrm{~kg}$ body weight, $150 \mathrm{mg} / \mathrm{day}$; orally for 28 days (A) or Paromomycin: $15 \mathrm{mg}$ (11 mg base) per kg body weight per day intramuscularly for 21 days (A).

5. Pentavalentantimonials: $20 \mathrm{mg} \mathrm{Sb5+/kg}$ per day intramuscularly or intravenously for 30 days in areas where they remain effective: Bangladesh, Nepal and the Indian states of Jharkhand, West Bengal and Uttar Pradesh (A).

Note: Amphotericin-B or Liposomal amphotericin B at higher dose should be used as rescue treatment in case of non-response

Source: WHO Technical Report Series (2010) Control of the leishmaniasis. WHO,Geneva [83]

Grade of evidence (A)- evidence based on at least one randomized controlled trial

amphotericin B available commercially that differ from each other with respect to dose, efficacy and toxicities. These are: i) liposomal amphotericin B (AmBisome'; Gilead Sciences); ii) Amphotericin B lipid complex (Abelcet'; ENZON Pharmaceuticals Inc.); iii) AmB cholesteryl sulfate complex, also called AmB colloidal dispersion [ABLC] (Amphocil; Sequus Pharmaceuticals); iv) FUNGISOME $^{\mathrm{mm}}$ (Lifecare Innovation Pvt Ltd); v) AmB emulsion (Amphomul, Bharat Serum and Vaccines, India); and vi) amphiphilic L-AmB (KALSOME ${ }^{\mathrm{rm}} 10$, Life care Innovation, Pvt. Ltd, India). Among these, Ambisome ${ }^{\odot}$ is tested in most of the clinical trials and is probably the most efficacious of all anti-leishmanial drugs currently available [26]. Most of the clinical trials of L-AmB for the treatment of VL have taken place in India, where more than 10 different regimens have been tested (Table 2). Most have been open-label, dosefinding studies or randomized controlled comparisons. Indian experience has demonstrated that L-AmB caused substantially less toxicity than conventional $\mathrm{AmB}$ or amphotericin B lipid complex (ABLC), but high cost is the major drawback. Much of research has been focused to reduce the course of L-AmB whilst retaining its efficacy, to limit the cost to patients. Sundar et al. showed that $15 \mathrm{mg} / \mathrm{kg}$ of Ambisome ${ }^{\ominus}(3 \mathrm{mg} / \mathrm{kg}$ on each of 5 injections) cured $96 \%$ patients [27]. Later on in separate study by Thakur et al. [28], and Sundar et al. [27, 29, 30] have demonstrated the efficacy and safety of Ambisome achieving efficacy rates in excess of $90 \%$ in single doses of $5-15 \mathrm{mg} / \mathrm{kg}$ (Table 2), making it an excellent treatment option for VL in the ISC. Low toxicity of L-AmB has made it best treatment option for HIV-VL co-infection patients. In a study by Sinha et al., excellent long term survival and retention rate were obtained; however, relapse within 2 year remained frequent [31]. It can be given safely in doses as high as $30-40 \mathrm{mg} / \mathrm{kg}$ body weight in HIVpositive VL patients [32, 33]. It has been speculated that lipid formulations enhance uptake by macrophages (the site of parasite replication) which results in the localization of the drug in the macrophage abundant areas in the body. Ambisome ${ }^{\circ}$ is currently being used as a first line drug for the treatment of VL in India, under the kalaazar elimination program.

Among other lipid formulations, Fungisome ${ }^{\mathrm{man}}$ with the dose $7.5 \mathrm{mg} / \mathrm{kg}$ daily for 2 days showed $100 \%$ cure rate (without any serious adverse effect) in an open label randomized study [34, 35]. Abelcet has shown cure rate 90-100 \% at total dose of $10-15 \mathrm{mg} / \mathrm{kg}$ in $\mathrm{Sb}^{\mathrm{V}}$ resistant patients [36]. Amphocil was evaluated at three different doses $(7.0,10$ and $15 \mathrm{mg} / \mathrm{kg}$ ) which showed final cure rate up to $97 \%$ [37]. Amphomul (single dose: $15 \mathrm{mg} / \mathrm{kg}$ body weight) was found highly effective and safe for treatment of VL [38]. KALSOME ${ }^{\mathrm{TM}}$ is still not tested on human VL, however, in murine model with $7.5 \mathrm{mg} / \mathrm{kg}$ double dose results in almost complete clearance of parasites from both liver and spleen [39].

\section{Paromomycin}

Paromomycin is a broad-spectrum aminoglycoside antibiotic produced from culture filtrates of Streptomyces krestomyceticus and with activity against a variety of Gram-positive and negative organisms, mycobacteria, protozoa. The anti-leishmanial activity of paromomycin was first demonstrated in the 1960s [40, 41] and subsequently confirmed in vitro and in vivo [42]. This drug was first tested in Kenya in 1980s for treatment of human VL [43]. It was registered for treatment of patients with VL in India in 2006 by Gland Pharma Ltd., Hyderabad, India, who is now the sole manufacturer for intramuscular paromomycin worldwide [44]. Several clinical trials have been conducted in Kenya, Sudan and India [43, 45-48], and all these studies have reported that paromomycin, when used as a single agent or in combination with sodium stibogluconate was highly efficacious and well tolerated in the treatment of VL. High efficacy rates for paromomycin (i.m) injection (dose- $11 \mathrm{mg} / \mathrm{kg}$ for 21 days) has been reported to $98.4 \%$ with initial cure (defined as the initial response after complete treatment), and the final cure (defined as a complete response with no evidence of relapse up to 6 months after an initial cure of 21 days of treatment) was approximately $94.6 \%$ [49]. Shortening the 
course of this drug from 21 to 14 days has subsequently shown inferior cure rate [50]. Pain at injection site, elevated liver function tests (LFTs); fever, proteinuria, vomiting, elevations in alkaline phosphatase and bilirubin values are the main adverse events associated with this drug. The mechanism of action of paromomycin is thought to be interference with protein synthesis in the ribosome of the target organism and inhibit the respiration [51].

\section{Miltefosine}

Miltefosine is an alkyl phospholipid compound was the first effective oral anti-leishmanial agent in VL, and registered for the treatment of VL in India in 2002, Germany in 2004, Colombia in 2005 and Bangladesh in 2006 (reviewed in ref. [52]). Miltefosine was originally intended for breast cancer and other solid tumours [53]. However, due to dose limiting gastro-intestinal toxicity, it could not be developed as an oral agent in cancer [54]. Evidence of excellent anti-leishmanial activity both in-vitro and in experimental animal models [55-57] prompted the clinical assessment of oral miltefosine in human VL in1996 [53]. Miltefosine was licensed for use in VL patients in India in 2002 following a Phase III clinical trial in which $94 \%$ long term cure rate was observed in a dose $50-100 \mathrm{mg} /$ day for 28 days [58]. It was licensed in Europe for treatment of HIV-VL co-infected patients in 2005 [59, 60]. However, because of its teratogenic effect in animals and its longterm residual persistence shown in humans, there is some concern on unrestricted use of the drug in women of child-bearing-age. Being orally administrable, miltefosine has a big advantage of domiciliary treatment. However, it has the drawback of poor compliance due to its prolonged treatment regimen well beyond the period in which there is almost a complete physical recovery of these patients. Also, with a long half-life of seven days, the chances of parasites developing resistance are high. A recent studies showed that after a decade of this drug use in Bihar (India), $6.8 \%$ of patients relapsed within 6 month of treatment [61]. These considerations suggest for alternative strategies to protect this drug from failure due to noncompliance or resistance and to prolong its clinically useful life. One such way is to combine a short course of miltefosine, to which compliance should be high, with a short course of another effective anti-leishmanial compound to obtain complete cure and to protect against single-agent resistance (Table 2).

\section{Sitamaquine}

Sitamaquine is another oral drug after miltefosine developed by Walter Reed Army Institute of Research (WRAIR, USA) in collaboration with GlaxoSmithKline (UK). Clinical trials using this drug have been completed in India, Kenya and Brazil [62-65] with cure rate ranging from 27 to $87 \%$. A major side effect was nephrotoxicity. Exact mechanism of this drug is not known but it is thought that it targets succinate dehydrogenate causing oxidative stress in leishmania parasites [66]. Further development of this molecule has been abandoned.

\section{Pentamidine}

Pentamidine, an aromatic diamidine that emerged earlier in Bihar, India as a second line drug to circumvent the problems of $\mathrm{Sb}^{\mathrm{V}}$ resistant in VL patients. However, due to inferior cure rate to $\mathrm{AmB}$ and toxicity issues (cardiac, hypotension, diabetes mellitus, gastrointestinal), use of this drug as monotherapy has been abandoned in endemic areas [67]. It is commercially available as Pentacarinat ${ }^{\circ}$ (Sanofi-Aventis). Pentamidine is currently recommended as secondary prophylaxis in HIV-VL co-infection. The mechanism of action of pentamidine in Leishmania and other kinetoplastids is the inhibition of active transport system and DNA-mitochondrial complex [68].

\section{Multidrug therapy}

In $\mathrm{VL}$, multidrug therapy has been advocated for several reasons: i) reduce the treatment time and cost; ii) slow the emergence of parasite resistance as mode of action of drugs will be different; iii) increase the efficacy rate even in the case of co-infection [20]. This strategy of multidrug treatment has been successfully used in the treatment of tuberculosis, malaria and leprosy. It also holds promises especially in complicated situations like HIV co-infection. Ideally, drugs used in combination therapy must be of synergistic and additive effect. One of the best approaches is to use one very active drug with a short half-life with second slow acting drug having a longer half-life to clear the remaining parasites. A comparative overview of different combination therapy studies for treatment of VL in India has been presented in Table 4, which suggests that multidrug therapies are safe and effective.

\section{Immune responses and immunomodulatory activity of anti-leishmanial drugs}

One of the major hurdles for developing an effective vaccine for $\mathrm{VL}$, as well as safer and more appropriate drugs and therapies, has been a limited understanding of the precise immune mechanisms required for controlling parasite growth (reviewed in ref. [69]). It has been thought that clinical efficacy of the disease treatment not only depends on direct effect of drugs alone, but an effective immune response also play critical role in final cure (Table 1). The use of biological molecules or compounds to stimulate or modulate innate and cell mediated immunity in order to achieve the therapeutic goal has been tested in both preclinical and clinical studies in treatment of leishmaniasis (reviewed in ref.[69]). For example, $\mathrm{Sb}^{\mathrm{V}}$ was not able to clear the parasites in $\mathrm{T}$ cell deficient 
Table 4 Studies on combination therapy for VL in India

\begin{tabular}{|c|c|c|c|c|c|c|c|}
\hline Authors & Year & Drug & Type of study & $\begin{array}{l}\text { Patients } \\
\text { (N) }\end{array}$ & Treatment scheme & $\begin{array}{l}\text { Definite cure } \\
(95 \% \mathrm{Cl})\end{array}$ & Reference \\
\hline \multirow[t]{3}{*}{$\begin{array}{l}\text { Thakur } \\
\text { et al. }\end{array}$} & \multirow[t]{3}{*}{1991} & \multirow[t]{3}{*}{$\begin{array}{l}\text { SSG and } \\
\text { Pentamidine }\end{array}$} & \multirow{3}{*}{$\begin{array}{l}\text { Randomised } \\
\text { controlled } \\
\text { comparative trial }\end{array}$} & \multirow[t]{3}{*}{312} & $\begin{array}{l}\text { Group-1 : Pentamidine (i.v) } 4 \mathrm{mg} / \mathrm{kg} / \text { day three times } \\
\text { weekly until parasitological cure was achieved }\end{array}$ & \multirow{3}{*}{$\begin{array}{l}\text { Group 1:78 \% } \\
\text { Group 2: } 84 \% \\
\text { Group 3: } 98 \%\end{array}$} & \multirow[t]{3}{*}{ [128] } \\
\hline & & & & & $\begin{array}{l}\text { Group-2: Pentamidine (i.v) } 4 \mathrm{mg} / \mathrm{kg} / \text { day three times } \\
\text { weekly + SSG (i.m) } 20 \text { mg/kg/day for } 20 \text { days }\end{array}$ & & \\
\hline & & & & & $\begin{array}{l}\text { Group-3: Pentamidine (i.v) } 4 \mathrm{mg} / \mathrm{kg} / \text { day three times } \\
\text { weekly until parasitological cure was achieved + SSG } \\
\text { (i.m) } 20 \mathrm{mg} / \mathrm{kg} / \text { day for } 20 \text { days }\end{array}$ & & \\
\hline \multirow{2}{*}{$\begin{array}{l}\text { Thakur } \\
\text { et al. }\end{array}$} & \multirow[t]{2}{*}{1992} & \multirow{2}{*}{$\begin{array}{l}\text { Paramomycin } \\
\text { and SSG }\end{array}$} & \multirow{2}{*}{$\begin{array}{l}\text { Non comparative } \\
\text { study }\end{array}$} & \multirow[t]{2}{*}{22} & Paramomycin (i.v) 12 mg/kg/day + & \multirow[t]{2}{*}{$81.8 \%$} & \multirow[t]{2}{*}{ [47] } \\
\hline & & & & & SSG (i.m) 20 mg/kg/day for 20 days & & \\
\hline \multirow[t]{3}{*}{$\begin{array}{l}\text { Thakur } \\
\text { et al. }\end{array}$} & \multirow[t]{3}{*}{2000} & \multirow[t]{3}{*}{$\begin{array}{l}\text { SSG and } \\
\text { Paramomycin }\end{array}$} & \multirow[t]{3}{*}{$\begin{array}{l}\text { Randomized } \\
\text { comparative study }\end{array}$} & \multirow[t]{3}{*}{149} & $\begin{array}{l}\text { Group 1: Paramomycin } 12 \text { mg/kg/day + SSG (i.m) } \\
20 \text { mg/kg/day for } 21 \text { days }\end{array}$ & \multirow{3}{*}{$\begin{array}{l}\text { Group 1:92.3\% } \\
\text { Group 2: } 93.8 \% \\
\text { Group 3: } 53.1 \%\end{array}$} & \multirow[t]{3}{*}{ [141] } \\
\hline & & & & & $\begin{array}{l}\text { Group 2: Paramomycin } 18 \text { mg/kg/day + SSG (i.m) } \\
20 \text { mg/kg/day for } 20 \text { days }\end{array}$ & & \\
\hline & & & & & Group 3: SSG (i.m) 20 mg/kg/day for 21 days & & \\
\hline \multirow[t]{2}{*}{$\begin{array}{l}\text { Das et } \\
\text { al. }\end{array}$} & \multirow[t]{2}{*}{2001} & \multirow[t]{2}{*}{$\begin{array}{l}\text { Pentamidine } \\
\text { and } \\
\text { Allopurinol }\end{array}$} & \multirow[t]{2}{*}{$\begin{array}{l}\text { Randomized } \\
\text { controlled } \\
\text { comparative trial }\end{array}$} & \multirow[t]{2}{*}{158} & $\begin{array}{l}\text { Group 1: Pentamidine (i.m) } 2 \mathrm{mg} / \mathrm{kg} / \text { day on } \\
\text { alternate days + allopurinol (oral) } 15 \mathrm{mg} / \mathrm{kg} / \text { day for } \\
30 \text { days }\end{array}$ & \multirow[t]{2}{*}{$\begin{array}{l}\text { Group 1: } 91.2 \% \\
\text { Group 2: } 74.3 \%\end{array}$} & \multirow[t]{2}{*}{ [67] } \\
\hline & & & & & $\begin{array}{l}\text { Group 2: : Pentamidine (i.m) } 2 \text { mg/kg/day on } \\
\text { alternate days for } 30 \text { days }\end{array}$ & & \\
\hline \multirow[t]{5}{*}{$\begin{array}{l}\text { Sundar } \\
\text { et al. }\end{array}$} & \multirow[t]{5}{*}{2008} & \multirow[t]{5}{*}{$\begin{array}{l}\text { L-AmB and } \\
\text { Miltefosine }\end{array}$} & \multirow{5}{*}{$\begin{array}{l}\text { Randomized non- } \\
\text { comparative, group } \\
\text { sequential }\end{array}$} & \multirow[t]{5}{*}{226} & Group1: L-AmB (i.v) $5 \mathrm{mg} / \mathrm{kg}$ single dose & $\begin{array}{l}\text { Group 1: } 91 \% \\
\text { (78-97); }\end{array}$ & \multirow[t]{5}{*}{ [142] } \\
\hline & & & & & $\begin{array}{l}\text { Group 2: L-AmB (i.v) } 5 \mathrm{mg} / \mathrm{kg} \text { single dose + } \\
\text { miltefosine } 100 \mathrm{mg} / \text { day for } 10 \text { days }\end{array}$ & $\begin{array}{l}\text { Group 2: } 98 \% \\
(87-100)\end{array}$ & \\
\hline & & & & & $\begin{array}{l}\text { Group3: L- AmB (i.v) } 5 \mathrm{mg} / \mathrm{kg} \text { single dose }+ \\
\text { miltefosine } 100 \mathrm{mg} / \text { day for } 14 \text { days }\end{array}$ & $\begin{array}{l}\text { Group 3: } 96 \% \\
\text { (84-99); }\end{array}$ & \\
\hline & & & & & $\begin{array}{l}\text { Group 4: L-AmB (i.v) } 3.75 \mathrm{mg} / \mathrm{kg} \text { single dose + } \\
\text { miltefosine } 100 \mathrm{mg} / \text { day for } 14 \text { days }\end{array}$ & $\begin{array}{l}\text { Group 4: } 96 \% \\
\text { (84-99); }\end{array}$ & \\
\hline & & & & & $\begin{array}{l}\text { Group 5: L-AmB (i.v) } 5 \mathrm{mg} / \mathrm{kg} \text { single dose }+ \\
\text { miltefosine } 100 \mathrm{mg} / \text { day for } 7 \text { days }\end{array}$ & $\begin{array}{l}\text { Group 5: } 98 \% \\
(87-100)\end{array}$ & \\
\hline $\begin{array}{l}\text { Sundar } \\
\text { et al. }\end{array}$ & 2010 & $\begin{array}{l}\text { L-AmB, } \\
\text { Miltefosine }\end{array}$ & $\begin{array}{l}\text { Non-randomized } \\
\text { multicentric trial }\end{array}$ & 135 & $\begin{array}{l}\text { L-AmB (i.v) } 5 \mathrm{mg} / \mathrm{kg} \text { for single dose + miltefosine } \\
\text { (oral) } 2.5 \mathrm{mg} / \mathrm{kg} / \text { day for } 14 \text { days }\end{array}$ & $91.9 \%$ & [143] \\
\hline \multirow[t]{4}{*}{$\begin{array}{l}\text { Sundar } \\
\text { et al. }\end{array}$} & 2011 & $\begin{array}{l}\text { AmB, L-AmB, } \\
\text { Paramomycin, }\end{array}$ & $\begin{array}{l}\text { Open label non- } \\
\text { inferiority random- }\end{array}$ & 634 & $\begin{array}{l}\text { Group 1: AmB (i.v) } 1 \mathrm{mg} / \mathrm{kg} \text { on alternate days for } \\
30 \text { days }\end{array}$ & $\begin{array}{l}\text { Group 1: } 93 \% \\
\text { (88-96); }\end{array}$ & {$[144]$} \\
\hline & & & & & $\begin{array}{l}\text { Group 2: L-AmB (i.v) } 5 \mathrm{mg} / \mathrm{kg} \text { for single dose + } \\
\text { miltefosine (oral) } 50 \mathrm{mg} / \mathrm{kg} \text { for } 7 \text { days }\end{array}$ & $\begin{array}{l}\text { Group 2: } 98 \% \\
\text { (93-99) }\end{array}$ & \\
\hline & & & & & $\begin{array}{l}\text { Group 3: Paramomycin (i.m) } 11 \text { mg/kg/day for } \\
10 \text { days }\end{array}$ & $\begin{array}{l}\text { Group 3: } 98 \% \\
\text { (93-99); }\end{array}$ & \\
\hline & & & & & $\begin{array}{l}\text { Group 4: Miltefosine (oral) } 50 \mathrm{mg} / \text { day for } 10 \text { days }+ \\
\text { paramomycin (i.m) } 11 \mathrm{mg} / \mathrm{kg} / \text { day for } 10 \text { days }\end{array}$ & $\begin{array}{l}\text { Group 4: } 99 \% \\
(95-100)\end{array}$ & \\
\hline
\end{tabular}

$\mathrm{BALB} / \mathrm{c}$ mice [70] as well as IFNy and IL-12 gene knockout mice [71, 72]. Treatment with exogenous IL-12 along with $\mathrm{Sb}^{\mathrm{V}}$ resulted in rapid clearance of L.donovani parasites (Table 1). Later on in subsequent separate study, it was reported that treatment with a single-dose anti-IL-10 receptor monoclonal antibody and daily low doses of $\mathrm{Sb}^{\mathrm{v}}$ dramatically enhance the therapeutic effects of $\mathrm{Sb}^{\mathrm{v}}$ in experimental mice model [73]. These findings strongly supported the idea that immune mechanisms play an important role in clinical outcome of disease. This was further demonstrated by studies on human VL, where stronger parasitological and clinical cure have been observed with recombinant human IFNy along with SSG compared with the SSG drug alone from India, Brazil and Kenya [74-76]. Basu et al. reported that SAG induces generation of reactive oxygen species (ROS) and nitric oxide (NO) dependent parasite killing via phosphorylation of ERK1/2 and p38 MAPK [77]. Similar immunomodulatory activity is also reported with miltefosine which induces IFN- $\gamma$, TNF- $\alpha$ and IL-12 production from macrophages [78]. In PKDL, miltefosine induces significant increase in levels of pro-inflammatory cytokines with concomitant decrease of anti-inflammatory cytokines via up-regulation of activation markers CD16 and CD 86 and 
down regulation of CD14 in circulating monocytes [79]. $\mathrm{AmB}$ has been shown to induce the production of TNF- $\alpha$ [80], IL-6 [81, 82], IL1ß [83-85] and M-CSF [86] from macrophage and monocytes and simultaneous suppression of mRNA expression of IL-10 and TNF- $\beta$ [87]. Therefore, immune based therapies in combination with chemotherapy that enhance immune responses to fight VL are of significant clinical interest. Such novel approaches may be of very useful for therapies to stimulate the immune system where patients are immunecompromised, such as those with HIV-VL co-infection.

\section{Treatment failure and parasite drug resistance}

Treatment of VL cases is complicated by patients' late presentation at an advanced stage of their illness; and treatment outcome mainly depends on the interaction between the drug, the parasite and the human host [88]. Treatment failure is well documented for $\mathrm{Sb}^{\mathrm{v}}$ but the mechanism is far from being completely understood. Most alarming reports came from Bihar (India), where $65 \%$ of VL-patients were found to be unresponsive to $\mathrm{Sb}^{\mathrm{v}}$ treatment, while in Nepal, recent reports indicate an unresponsiveness rate of up to $24 \%$ in one district $[89,90]$. Recently, it was reported that multiple $\mathrm{Sb}^{\mathrm{v}}$ resistance mechanism are circulating in the Indian subcontinent [91] including the loss of metal reduction, over-expression of thiol metabolism enzymes, multi drug resistant transporter and reduced drug uptake due to decreased expression of aquaporins in different experimental models [92]. However, knowledge gained from transcriptional profiling studies and proteomic approaches emphasized the involvement of HSP's, histones, calpain-related proteins and MAPK [93]. While the metabolomics studies have identified many changes and variation in the lipid composition that alters the membrane fluidity [94] and amino acid composition [95]. These facts suggested for the adaptability of the parasite, and therefore, genome plasticity in Leishmania which has further been validated by Downing and colleagues, to prove the existence of different genetic background in drug resistant parasites within a single geographical area [96] thereby consolidating the idea for the existence of drug resistant phenotypes in the population. Many other reports for the drug resistance have been available attributing to the role of efflux transporters, aquaporins, and alterations in the intracellular thiol levels in drug resistant clinical isolates has been discussed ahead.

AmB resistance, though rare, has been known to result in changes in the sterol profile where the ergosterol is replaced by its precursor cholesta-5,7,24-trien-3-ol in the membrane of parasite thereby reducing its affinity towards the drug. Amplification in the extra chromosomal DNA which has been directly associated with the resistant phenotypes [97]. The mechanism of resistance has further been explored by the proteomic analysis that shed light on the involvement of energetic pathways which are upregulated including the glycolytic and TCA cycle while documenting the role of reactive oxygen species (ROS) scavenging pathways and heat shock proteins as additional weapon for protection against the drug induced stress [98]. As mentioned above, the role for the efflux pump (MDR) remains to be the important factor driving the drug resistance together with the thiol machinery for better coping up the ROS induced oxidative stress [99].

Emerging resistance against miltefosine is a matter of serious concern as it is the only available oral antileishmanial drug. Incomplete treatment and long half-life of this drug in the circulation has been thought to be one of the factors for driving the parasite machinery for adaptability against the drug induced stress. The exact mechanism of which could be imputed to the allele specific mutations in P-glycoprotein-LdRos3 and LdMT [100] which are responsible for drug uptake in ideal conditions, but the mutation causes the gene inactivation and consequently decreasing the drug accumulation and drug translocation in parasite. Apart from above mentioned reasons increased drug efflux has been another threatening cause of drug resistance. Mode of parasite killing involves the induction of apoptosis by accumulation of ROS but the resistant phenotype has been known to alter the cellular machinery and thereby reducing ROS mediated apoptotic phenomenon. The resistant phenotypes have also been known to be armed for coping up the oxidative stress by up-regulating several important enzymes as superoxide dismutase and ascorbate peroxidase [101].

Paromomycin, another drug targeting the parasite mitochondrial protein synthesis machinery has led the parasite to emerge as a strong survivor with reduced drug binding to the surface, increased translational activities with up-regulation of glycolytic enzymes and intracellular proteins, high expression levels of ATP-Binding Cassette $(\mathrm{ABC})$ transporters [51]. The developments in the field of omics technologies like DNA microarray, MALDI, SILAC has further provided newer insight into the underlying mechanisms for the changes in gene copy number either by gene deletion, amplification or gene rearrangements.

Emergence and spreading of drug resistance can dramatically jeopardize the VL control program relying on chemotherapy, as shown in malaria. It is thought that inadequate treatment, either regimen or treatment duration, is the main cause for failure of treatment and resulting in emergence of drug resistance [102]. Nothing is known about the dynamics of drug resistant Leishmania populations in the presence or absence of drug pressure. Therefore, monitoring of drug efficacy and early reporting are essential to bring corrective actions in drug policy. This requires tools, a standardized way to use them and a structure to implement them: in the mid-term, a network 
of sentinel sites could be established by the VL elimination program, like it was done in East Africa for malaria [103].

\section{What are the possible solutions?}

Although considerable scientific progress has been made over the past decade in the broad domain of leishmaniasis, including the genome sequencing of various pathogens causing different form of leishmaniasis, these have not had any impact so far on the quality of clinical care for VL in the field due to very limited number of available antileishmanial drugs. It is very important to safeguard the effectiveness of these drugs in order to cure patients and to sustain the VL control. For this, the uninterrupted supply of quality drugs, the promotion of treatment adherence and the monitoring of treatment effectiveness as well as drug resistance will be pivotal. One of the major hurdles for identifying VL patients who are unlikely to respond adequately to chemotherapy, has been a limited understanding of the precise immune mechanisms required for controlling parasite growth, particularly the immune mechanisms that are generated following drug treatment. Anti-leishmanial drugs as monotherapy are high risk of emergence of resistant parasites [16], therefore multidrug therapy needs to be recommended. Another important problem is disease relapse following drug treatment, and at present there are no good prognostic markers to identify individuals that might fail drug treatment. Because the knowledge on mechanisms of emergence of drug resistance, its dynamics and the impact of the introduction of new drugs is poor, and validated methods to monitor treatment of effectiveness under routine conditions do not exist, it is therefore very urgent to develop new tools to allow monitoring treatment effectiveness and drug resistance in order to support the drug policy of the VL elimination program. Furthermore, treatment outcome (the end of treatment) is not definite and patients need to be followed up 6 months after treatment to assess cure. This makes monitoring treatment effectiveness in routine conditions difficult, as patients may not come back for the requested visit 6 months post-treatment. Hence there is a need to compare existing and develop new approaches to monitor treatment effectiveness at the program level. Several possibilities exist: to work with proxy indicators, to develop a method adapted from the retrospective cohort analysis used in TB programs, to give incentives as transport allowances to patients etc.

Importantly, patients with PKDL represent an important but largely neglected reservoir of infection that perpetuates anthroponotic Leishmania donovani disease in India, and focal VL outbreaks have been linked to an index case of PKDL [104]. Treatment of PKDL in India is widely regarded as unsatisfactory, and the low incidence of PKDL in India makes any prospective clinical study challenging. Lack of animal models for PKDL is another challenge for laboratory testing of new drugs. Therefore, more research on an intervention that can reduce the risk of developing PKDL; and characterization of parasite strain are needed to resolve the mystery of this disease.

The use of chemotherapy alone as control tool is limited by the fact that only sick people will be treated. There are asymptomatic carriers of the parasite (estimated 6 times more than VL patients) [105-107], and in the absence of chemoprophylaxis of leishmaniasis, these will obviously not be exposed to the drug [3]. Exact role of asymptomatic infection in disease transmission is unknown, but control programs should take them into consideration, hence role of asymptomatic should be quickly elucidated in context to VL transmission.

Last but not the least, not only VL treatment programs should be maintained and improved, but research should also be taken into consideration those parasite reservoirs in populations in order to reduce the risk of transmission. Programs based on management of vector control should be continued as a critical part of treatment strategy. Research on development of safe and effective vaccine have to be promoted that could make a significant impact on the re-emergence of VL cases and sustain the transmission level in endemic areas.

\section{Conclusion}

In the absence of effective vaccine and vector control measures, control of VL and PKDL almost exclusively depends on chemotherapy. The available drugs are costly and may require hospitalization that needs monitoring which cause substantial loss of income for affected families. Emergence of drug resistance further complicates the treatment of disease. Multidrug regimens for VL hold much promise and, experiences with single dose $\mathrm{L}-\mathrm{AmB}$ are excellent and this will have obvious benefits to the patients who will not require hospital care and loss of wages. However, more studies are required on treatment of PKDL and HIV-VL coinfections as they serve as silent reservoir in endemic areas, and as such will jeopardize the sustainability of VL elimination in the ISC. We have now entered in the VL elimination year, and it is best time to repeat the experience of smallpox and polio eradication in order to open a whole new public health era for next generations.

\section{Additional file}

Additional file 1: Multilingual abstracts in the six official working languages of the United Nations. (PDF $277 \mathrm{~kb}$ )

\section{Abbreviations}

AmB: Amphotericin B deoxycholate; CD: cluster of differentiation; ERK: extra cellular signal regulated kinases; i.v: intravenously; IL-10: interleukin-10;

IM: intramuscularly; ISC: Indian subcontinent; L-AmB: Liposomal Amphotericin B; MAPK: mitogen activated protein kinases; M-CSF: macrophase colony stimulating factor; MDR: multi drug resistance; NO: nitric oxide; PKDL: post 
kala-azar dermal leishmaniasis; R\&D: research and development; ROS: reactive oxygen species; SSG: sodium stibogluconate; TCA: tri cyclic acid cycle; TNF: Tumor necrosis factor; VL: visceral leishmaniasis.

\section{Competing interest}

The authors declare that they have no competing interests.

\section{Authors' contributions}

OPS and SS conceived the idea, collected and organized the data of review. OPS, BS, JC and SS critically read, edited and approved the final version of article. No writing assistance was utilized in the production of this manuscript.

\section{Acknowledgement}

This work was supported by Extramural Programme of the National Institute of Allergy and Infectious Disease (NIAID), National Institute of Health (TMRC Grant No.P50Al074321) and grant from the Bill \& Melinda Gates Foundation (OPP 1117011). Om Prakash Singh has received travel support to attend scientific meeting from the Council of Scientific and Industrial Research (CSIR), Delhi; Department of Biotechnology (DBT), Delhi and Immunology Foundation, Delhi. The authors have no other relevant affiliations or financial involvement with any organization or entity with a financial interest in or financial conflict with the subject matter or materials discussed in the manuscript apart from those disclosed. Authors would like to dedicate this article to all those patients who lost their lives during drug trials in various part of the world.

\section{Received: 2 November 2015 Accepted: 2 March 2016}

\section{Published online: 08 March 2016}

\section{References}

1. Narain JP, Dash AP, Parnell B, Bhattacharya SK, Barua S, Bhatia R, et al. Elimination of neglected tropical diseases in the South-East Asia Region of the World Health Organization. Bull World Health Organ. 2010;88(3):206-10.

2. WHO. Accelerating Work to Overcome the Global Impact of Neglected Tropical Dieases: A Roadmap for implementation. http://www.who.int/ neglected_diseases/NTD_RoadMap_2012_Fullversion.pdf. 2011.

3. Singh $O P$, Hasker $E$, Sacks $D$, Boelaert $\bar{M}$, Sundar S. Asymptomatic Leishmania Infection: A New Challenge for Leishmania Control. Clin Infect Dis. 2014;58:1424-9.

4. Singh $\mathrm{OP}$, Sundar S. Developments in diagnosis of visceral leishmaniasis in the elimination era. J Parasitol Res 2015, http://dx.doi.org/10.1155/2015/239469.

5. Alvar J, Velez ID, Bern C, Herrero M, Desjeux P, Cano J, et al. Leishmaniasis worldwide and global estimates of its incidence. PLoS ONE. 2012;7(5):e35671.

6. Boelaert M, Meheus F, Sanchez A, Singh SP, Vanlerberghe V, Picado A, et al. The poorest of the poor: a poverty appraisal of households affected by visceral leishmaniasis in Bihar, India. Trop Med Int Health. 2009;14(6):639-44.

7. Meheus F, Balasegaram M, Olliaro P, Sundar S, Rijal S, Faiz MA, Boelaert M. Cost-effectiveness analysis of combination therapies for visceral leishmaniasis in the Indian subcontinent. PLoS Negl Trop Dis 2010;4(9). doi: 10.1371/journal.pntd.0000818.

8. WHO. Regional Strategic Framework for Elimination of Kala-azar from the South-East Asia Region (2005-2015). http://www.searo.who.int/entity/ world_health_day/2014/KA_CD239.pdf. 2005

9. Health Ministers comit to eliminate kala-azar (media advisory), New Delhi: WHO Regional Officefor South-East Asia. 2014. http://www.searo.who.int/ mediacentre/releases/2014/pr1580/en/

10. DNDi Annual Report. http://www.dndi.org/flippable/annualreport2012/.

11. Mukhopadhyay D, Dalton JE, Kaye PM, Chatterjee M. Post kala-azar dermal leishmaniasis: an unresolved mystery. Trends Parasitol. 2014;30(2):65-74.

12. Burza S, Mahajan R, Sinha PK, van Griensven J, Pandey K, Lima MA, et al. Visceral leishmaniasis and HIV co-infection in Bihar, India: long-term effectiveness and treatment outcomes with liposomal amphotericin B (AmBisome). PLoS Negl Trop Dis. 2014:8(8):e3053.

13. van Griensven J, Zijlstra EE, Hailu A. Visceral leishmaniasis and HIV coinfection: time for concerted action. PLoS Negl Trop Dis. 2014;8(8):e3023.

14. Stauch A, Duerr HP, Dujardin JC, Vanaerschot M, Sundar S, Eichner M. Treatment of visceral leishmaniasis: model-based analyses on the spread of antimonyresistant L. donovani in Bihar, India. PLoS Negl Trop Dis. 2013;6(12):e1973.
15. Chowdhury R, Mondal D, Chowdhury V, Faria S, Alvar J, Nabi SG, et al. How far are we from visceral leishmaniasis elimination in Bangladesh? An assessment of epidemiological surveillance data. PLoS Negl Trop Dis. 2014;8(8):e3020.

16. Sundar S, Chakravarty J. An update on pharmacotherapy for leishmaniasis. Expert Opin Pharmacother. 2015;16(2):237-52.

17. Krauth-Siegel RL, Comini MA. Redox control in trypanosomatids, parasitic protozoa with trypanothione-based thiol metabolism. Biochim Biophys Acta. 2008;1780(11):1236-48

18. Jha TK, Giri YN, Singh TK, Jha S. Use of amphotericin B in drug-resistant cases of visceral leishmaniasis in north Bihar, India. Am J Trop Med Hyg 1995:52(6):536-8.

19. Thakur CP, Sinha GP, Pandey AK, Barat D, Sinha PK. Amphotericin B in resistant kala-azar in Bihar. Natl Med J India. 1993:6(2):57-60.

20. Olliaro PL, Guerin PJ, Gerstl S, Haaskjold AA, Rottingen JA, Sundar S. Treatment options for visceral leishmaniasis: a systematic review of clinical studies done in India, 1980-2004. Lancet Infect Dis. 2005;5(12):763-74.

21. Monge-Maillo B, Lopez-Velez R. Therapeutic options for old world cutaneous leishmaniasis and new world cutaneous and mucocutaneous leishmaniasis. Drugs. 2013:73(17):1889-920.

22. Thakur CP, Ahmed S. Observations on amphotericin B treatment of kala-azar given in a rural set up in Bihar, India. Indian J Med Res. 2001;113:14-8.

23. Sundar S, Chakravarty J. Recent advances in the diagnosis and treatment of kala-azar. Natl Med J India. 2012;25(2):85-9.

24. Ramos H, Valdivieso E, Gamargo M, Dagger F, Cohen BE. Amphotericin B kills unicellular leishmanias by forming aqueous pores permeable to small cations and anions. J Membr Biol. 1996;152(1):65-75.

25. Chattopadhyay A, Jafurulla M. A novel mechanism for an old drug: amphotericin B in the treatment of visceral leishmaniasis. Biochem Biophys Res Commun. 2011:416(1-2):7-12.

26. Bern C, Adler-Moore J, Berenguer J, Boelaert M, den Boer M, Davidson RN, et al. Liposomal amphotericin B for the treatment of visceral leishmaniasis. Clin Infect Dis. 2006:43(7):917-24.

27. Sundar S, Chakravarty J, Agarwal D, Rai M, Murray HW. Single-dose liposomal amphotericin B for visceral leishmaniasis in India. N Engl J Med. 2010:362(6):504-12.

28. Thakur CP. A single high dose treatment of kala-azar with Ambisome (amphotericin B lipid complex): a pilot study. Int J Antimicrob Agents. 2001; 17(1):67-70

29. Sundar S, Jha TK, Thakur CP, Mishra M, Singh VP, Buffels R. Single-dose liposomal amphotericin B in the treatment of visceral leishmaniasis in India: a multicenter study. Clin Infect Dis. 2003:37(6):800-4.

30. Sundar S, Agrawal G, Rai M, Makharia MK, Murray HW. Treatment of Indian visceral leishmaniasis with single or daily infusions of low dose liposomal amphotericin B: randomised trial. BMJ. 2001;323(7310):419-22.

31. Sinha PK, van Griensven J, Pandey K, Kumar N, Verma N, Mahajan R, et al. Liposomal amphotericin B for visceral leishmaniasis in human immunodeficiency virus-coinfected patients: 2-year treatment outcomes in Bihar, India. Clin Infect Dis. 2011:53(7):e91-8.

32. Adler-Moore J, Proffitt RT. Am Bisome: liposomal formulation, structure, mechanism of action and pre-clinical experience. J Antimicrob Chemother. 2002;49 Suppl 1:21-30

33. Russo R, Nigro LC, Minniti S, Montineri A, Gradoni L, Caldeira L, et al. Viscera leishmaniasis in HIV infected patients: treatment with high dose liposomal amphotericin B (AmBisome). J Infect. 1996:32(2):133-7.

34. Sundar S, Singh A, Rai M, Chakravarty J. Single-Dose Indigenous Liposomal Amphotericin B in the Treatment of Indian Visceral Leishmaniasis: A Phase 2 Study. Am J Trop Med Hyg. 2015;14-0259.

35. Goswami RP, Goswami RP, Das S, Satpati A, Rahman M. Short-Course Treatment Regimen of Indian Visceral Leishmaniasis with an Indian Liposomal Amphotericin B Preparation (Fungisome ${ }^{\mathrm{TM}}$ ). Am J Trop Med Hyg. 2016;94(1):93-8.

36. Sundar S, Rai M. Treatment of visceral leishmaniasis. Expert Opin Pharmacother. 2005;6(16):2821-9.

37. Sundar S, Mehta $H$, Chhabra A, Singh V, Chauhan V, Desjeux $P$, et al. Amphotericin B colloidal dispersion for the treatment of Indian visceral leishmaniasis. Clin Infect Dis. 2006:42(5):608-13.

38. Sundar S, Singh A, Agarwal D, Rai M, Agrawal N, Chakravarty J. Safety and efficacy of high-dose infusions of a preformed amphotericin B fat emulsion for treatment of Indian visceral leishmaniasis. Am J Trop Med Hyg. 2009;80(5):700-3.

39. Asad M, Bhattacharya P, Banerjee A, Ali N. Therapeutic and immunomodulatory activities of short-course treatment of murine visceral leishmaniasis with KALSOME ${ }^{\mathrm{TM}} 10$, a new liposomal amphotericin B. BMC Inf Dis. 2015;15:188. doi:10.1186/s12879-015-0928-6. 
40. Kellina Ol. A study of experimental cutaneous leishmaniasis in white mice. Med Parazitol (Mosk). 1961;30:684-91.

41. Neal RA. The effect of antibiotics of the neomycin group on experimental cutaneous leishmaniasis. Ann Trop Med Parasitol. 1968;62(1):54-62.

42. Neal RA, Allen S, McCoy N, Olliaro P, Croft SL. The sensitivity of Leishmania species to aminosidine. J Antimicrob Chemother. 1995;35(5):577-84.

43. Chunge CN, Owate J, Pamba HO, Donno L. Treatment of visceral leishmaniasis in Kenya by aminosidine alone or combined with sodium stibogluconate. Trans R Soc Trop Med Hyg. 1990;84(2):221-5.

44. Sundar S, Chakravarty J. Paromomycin in the treatment of leishmaniasis. Expert Opin Investig Drugs. 2008;17(5):787-94.

45. Seaman J, Pryce D, Sondorp HE, Moody A, Bryceson AD, Davidson RN. Epidemic visceral leishmaniasis in Sudan: a randomized trial of aminosidine plus sodium stibogluconate versus sodium stibogluconate alone. J Infect Dis. 1993;168(3):715-20.

46. Jha BB. Fluconazole in visceral leishmaniasis. Indian Pediatr. 1998;35(3):268-9.

47. Thakur CP, Olliaro P, Gothoskar S, Bhowmick S, Choudhury BK, Prasad S, et al. Treatment of visceral leishmaniasis (kala-azar) with aminosidine (= paromomycin)-antimonial combinations, a pilot study in Bihar, India. Trans $\mathrm{R}$ Soc Trop Med Hyg. 1992;86(6):615-6.

48. Thakur CP, Bhowmick S, Dolfi L, Olliaro P. Aminosidine plus sodium stibogluconate for the treatment of Indian kala-azar: a randomized dosefinding clinical trial. Trans R Soc Trop Med Hyg. 1995;89(2):219-23.

49. Sundar S, Jha TK, Thakur CP, Sinha PK, Bhattacharya SK. Injectable paromomycin for Visceral leishmaniasis in India. N Engl J Med. 2007;356(25):2571-81.

50. Sundar S, Agrawal N, Arora R, Agarwal D, Rai M, Chakravarty J. Short-course paromomycin treatment of visceral leishmaniasis in India: 14-day vs 21-day treatment. Clin Infect Dis. 2009;49(6):914-8.

51. Chawla B, Jhingran A, Panigrahi A, Stuart KD, Madhubala R. Paromomycin affects translation and vesicle-mediated trafficking as revealed by proteomics of paromomycin -susceptible -resistant Leishmania donovani. PLOS ONE. 2011;6(10):e26660

52. Dorlo TP, Balasegaram M, Beijnen JH, de Vries PJ. Miltefosine: a review of its pharmacology and therapeutic efficacy in the treatment of leishmaniasis. J Antimicrob Chemother. 2012;67(11):2576-97.

53. Sundar S, Olliaro PL. Miltefosine in the treatment of leishmaniasis: Clinical evidence for informed clinical risk management. Ther Clin Risk Manag. 2007; 3(5):733-40.

54. Dummer R, Krasovec M, Röger J, Sindermann H, Burg G. Topical administration of hexadecylphosphocholine in patients with cutaneous lymphomas: results of a phase I/II study. J Am Acad Dermatol. 1993;29(6):963-70.

55. Croft SL, Neal RA, Pendergast W, Chan JH. The activity of alkyl phosphorylcholines and related derivatives against Leishmania donovani. Biochem Pharmacol. 1987;36(16):2633-6.

56. Croft SL, Snowdon D, Yardley V. The activities of four anticancer alkyllysophospholipids against Leishmania donovani, Trypanosoma cruzi and Trypanosoma brucei. J Antimicrob Chemother. 1996;38(6):1041-7.

57. Kuhlencord A, Maniera T, Eibl H, Unger C. Hexadecylphosphocholine: oral treatment of visceral leishmaniasis in mice. Antimicrob Agents Chemother 1992;36(8):1630-4

58. Sundar S, Jha TK, Thakur CP, Engel J, Sindermann H, Fischer C, et al. Oral miltefosine for Indian visceral leishmaniasis. N Engl J Med. 2002;347(22):1739-46.

59. Berman J. Miltefosine to treat leishmaniasis. Expert Opin Pharmacother. 2005;6(8):1381-8.

60. Sindermann $H$, Engel J. Development of miltefosine as an oral treatment for leishmaniasis. Trans R Soc Trop Med Hyg. 2006;100 Suppl 1:S17-20.

61. Sundar S, Singh A, Rai M, Prajapati VK, Singh AK, Ostyn B, et al. Efficacy of miltefosine in the treatment of visceral leishmaniasis in India after a decade of use. Clin Infect Dis. 2012;55(4):543-50.

62. Sherwood JA, Gachihi GS, Muigai RK, Skillman DR, Mugo M, Rashid JR, et al. Phase 2 efficacy trial of an oral 8-aminoquinoline (WR6026) for treatment of visceral leishmaniasis. Clin Infect Dis. 1994;19(6):1034-9.

63. Dietze R, Carvalho SF, Valli LC, Berman J, Brewer T, Milhous W, et al. Phase 2 trial of WR6026, an orally administered 8-aminoquinoline, in the treatment of visceral leishmaniasis caused by Leishmania chagasi. Am J Trop Med Hyg. 2001;65(6):685-9.

64. Jha TK, Sundar S, Thakur CP, Felton JM, Sabin AJ, Horton J. A phase II doseranging study of sitamaquine for the treatment of visceral leishmaniasis in India. Am J Trop Med Hyg. 2005;73(6):1005-11.

65. Wasunna MK, Rashid JR, Mbui J, Kirigi G, Kinoti D, Lodenyo H, et al. A phase II dose-increasing study of sitamaquine for the treatment of visceral leishmaniasis in Kenya. Am J Trop Med Hyg. 2005;73(5):871-6.
66. Carvalho L, Luque-Ortega JR, Lopez-Martin C, Castanys S, Rivas L, Gamarro F. The 8-aminoquinoline analogue sitamaquine causes oxidative stress in Leishmania donovani promastigotes by targeting succinate dehydrogenase. Antimicrob Agents Chemother. 2011;55(9):4204-10.

67. Das VN, Ranjan A, Sinha AN, Verma N, Lal CS, Gupta AK, et al. A randomized clinical trial of low dosage combination of pentamidine and allopurinol in the treatment of antimony unresponsive cases of visceral leishmaniasis. J Assoc Physicians India. 2001;49:609-13.

68. Hwan J. Visceral leishmaniasis: Revisiting current treatments and approaches for future discoveries. Acta Trop. 2016;115:113-23.

69. Singh OP, Sundar S. Immunotherapy and targeted therapies in treatment of visceral leishmaniasis: current status and future prospects. Front Immunol. 2014;5:296.

70. Murray HW, Oca MJ, Granger AM, Schreiber RD. Requirement for T cells and effect of lymphokines in successful chemotherapy for an intracellular infection. Experimental visceral leishmaniasis. J Clin Invest. 1989;83(4):1253-7.

71. Murray HW. Mononuclear cell recruitment, granuloma assembly, and response to treatment in experimental visceral leishmaniasis: intracellular adhesion molecule 1-dependent and -independent regulation. Infect Immun. 2000;68(11):6294-9.

72. Murray HW, Montelibano C, Peterson R, Sypek JP. Interleukin-12 regulates the response to chemotherapy in experimental visceral Leishmaniasis. J Infect Dis. 2000;182(5):1497-502.

73. Murray HW, Flanders KC, Donaldson DD, Sypek JP, Gotwals PJ, Liu J, et al. Antagonizing deactivating cytokines to enhance host defense and chemotherapy in experimental visceral leishmaniasis. Infect Immun. 2005; 73(7):3903-11.

74. Sundar S, Rosenkaimer F, Lesser ML, Murray HW. Immunochemotherapy for a systemic intracellular infection: accelerated response using interferongamma in visceral leishmaniasis. J Infect Dis. 1995;171(4):992-6.

75. Badaro R, Falcoff E, Badaro FS, Carvalho EM, Pedral-Sampaio D, Barral A, et al. Treatment of visceral leishmaniasis with pentavalent antimony and interferon gamma. N Engl J Med. 1990;322(1):16-21.

76. Squires KE, Rosenkaimer F, Sherwood JA, Forni AL, Were JB, Murray HW. Immunochemotherapy for visceral leishmaniasis: a controlled pilot trial of antimony versus antimony plus interferon-gamma. Am J Trop Med Hyg. 1993;48(5):666-9.

77. Mookerjee Basu J, Mookerjee A, Sen P, Bhaumik S, Sen P, Banerjee S, et al. Sodium antimony gluconate induces generation of reactive oxygen species and nitric oxide via phosphoinositide 3-kinase and mitogen-activated protein kinase activation in Leishmania donovani-infected macrophages. Antimicrob Agents Chemother. 2006;50(5):1788-97.

78. Wadhone P, Maiti M, Agarwal R, Kamat V, Martin S, Saha B. Miltefosine promotes IFN-gamma-dominated anti-leishmanial immune response. J Immunol. 2009;182(11):7146-54.

79. Mukhopadhyay D, Das NK, Roy S, Kundu S, Barbhuiya JN, Chatterjee M. Miltefosine effectively modulates the cytokine milieu in Indian post kala-azar dermal leishmaniasis. J Infect Dis. 2011;204(9):1427-36.

80. Tokuda Y, Tsuji M, Yamazaki M, Kimura S, Abe S, Yamaguchi H. Augmentation of murine tumor necrosis factor production by amphotericin $B$ in vitro and in vivo. Antimicrob Agents Chemother. 1993;37(10):2228-30.

81. Ghezzi MC, Raponi G, Filadoro F, Mancini C. The release of TNF-alpha and IL-6 from human monocytes stimulated by filtrates of Candida albicans after treatment with amphotericin B. J Antimicrob Chemother. 1994;33(5):1039-43.

82. Louie A, Baltch AL, Smith RP, Franke MA, Ritz WJ, Singh JK, et al. Fluconazole and amphotericin B antifungal therapies do not negate the protective effect of endogenous tumor necrosis factor in a murine model of fatal disseminated candidiasis. J Infect Dis. 1995;171(2):406-15.

83. Golenser J, Domb A. New formulations and derivatives of amphotericin B for treatment of leishmaniasis. Mini Rev Med Chem. 2006:6(2):153-62.

84. Chia JK, McManus EJ. In vitro tumor necrosis factor induction assay for analysis of febrile toxicity associated with amphotericin B preparations. Antimicrob Agents Chemother. 1990;34(5):906-8.

85. Cleary JD, Chapman SW, Nolan RL. Pharmacologic modulation of interleukin-1 expression by amphotericin B-stimulated human mononuclear cells. Antimicrob Agents Chemother. 1992;36(5):977-81.

86. Fujita H, Masuda H, Nakajima T, Yada K, Watanabe M, Kagitani Y. Protective effect of human macrophage colony-stimulating factor on fungal infection (2). In vitro effect of human macrophage colony-stimulating factor on systemic aspergillosis and in vitro effect on the activities of macrophage. Kansenshogaku Zasshi. 1995;69(5):582-9. 
87. Murray HW, Delph-Etienne S. Roles of endogenous gamma interferon and macrophage microbicidal mechanisms in host response to chemotherapy in experimental visceral leishmaniasis. Infect Immun. 2000;68(1):288-93.

88. Sundar S, Singh A, Singh OP. Strategies to overcome antileishmanial drugs unresponsiveness. J Trop Med. 2014;2014:646932. doi:10.1155/2014/646932.

89. Sundar S. Drug resistance in Indian visceral leishmaniasis. Trop Med Int Health. 2001;6(11):849-54.

90. Sundar S, More DK, Singh MK, Singh VP, Sharma S, Makharia A, et al. Failure of pentavalent antimony in visceral leishmaniasis in India: report from the center of the Indian epidemic. Clin Infect Dis. 2000;31(4):1104-7.

91. Decuypere S, Vanaerschot M, Brunker K, Imamura H, Muller S, Khanal B, et al. Molecular mechanisms of drug resistance in natural Leishmania populations vary with genetic background. PLoS Negl Trop Dis. 2012;6(2):e1514.

92. Croft SL, Sundar S, Fairlamb AH. Drug resistance in leishmaniasis. Clin Microbiol Rev. 2006:19(1):111-26.

93. Kumar A, Sisodia B, Misra P, Sundar S, Shasany AK, Dube A. Proteome mapping of overexpressed membrane-enriched and cytosolic proteins in sodium antimony gluconate (SAG) resistant clinical isolate of Leishmania donovani. Br J Clin Pharmacol. 2010;70(4):609-17.

94. t'Kindt R, Scheltema RA, Jankevics A, Brunker K, Rijal S, Dujardin JC, et al. Metabolomics to unveil and understand phenotypic diversity between pathogen populations. PLoS Negl Trop Dis. 2010;4(11):e904.

95. Canuto GA, Castilho-Martins EA, Tavares M, Lopez-Gonzalvez A, Rivas L, Barbas C. CE-ESI-MS metabolic fingerprinting of Leishmania resistance to antimony treatment. Electrophoresis. 2012;33(12):1901-10.

96. Downing T, Imamura H, Decuypere S, Clark TG, Coombs GH, Cotton JA, et al. Whole genome sequencing of multiple Leishmania donovani clinical isolates provides insights into population structure and mechanisms of drug resistance. Genome Res. 2011;21(12):2143-56.

97. Singh AK, Papadopoulou B, Ouellette M. Gene amplification in amphotericin B-resistant Leishmania tarentolae. Exp Parasitol. 2001;99(3):141-7.

98. Brotherton MC, Bourassa S, Legare D, Poirier GG, Droit A, Ouellette M. Quantitative proteomic analysis of amphotericin B resistance in Leishmania infantum. Int J Parasitol Drugs Drug Resist. 2014;4(2):126-32.

99. Purkait B, Kumar A, Nandi N, Sardar AH, Das S, Kumar S, et al. Mechanism of amphotericin $B$ resistance in clinical isolates of Leishmania donovani. Antimicrob Agents Chemother. 2012;56(2):1031-41.

100. Bhandari V, Kulshrestha A, Deep DK, Stark O, Prajapati VK, Ramesh V, et al. Drug susceptibility in Leishmania isolates following miltefosine treatment in cases of visceral leishmaniasis and post kala-azar dermal leishmaniasis. PLoS Negl Trop Dis. 2012;6(5):e1657.

101. Das M, Saudagar P, Sundar S, Dubey V. Miltefosine-unresponsive Leishmania donovani has a greater ability than miltefosine-responsive $L$. donovani to resist reactive oxygen species. FEBS J. 2013;280(19):4807-15. doi:10.1111/febs.12449.

102. Rai K, Cuypers B, Bhattarai NR, Uranw S, Berg M, Ostyn B, et al. Relapse after treatment with miltefosine for visceral leishmaniasis is associated with increased infectivity of the infecting Leishmania donovani strain. MBio. 2013;4(5):e00611-3.

103. EANMAT. Monitoring antimalarial drug resistance within National Malaria Control Programmes: the EANMAT experience. Trop Med Int Health. 2001; 6(11):891-8.

104. Addy M, Nandy A. Ten years of kala-azar in west Bengal, Part I. Did postkala-azar dermal leishmaniasis initiate the outbreak in 24-Parganas? Bull World Health Organ. 1992;70(3):341-6.

105. Hasker E, Malaviya P, Gidwani K, Picado A, Ostyn B, Kansal S, et al. Strong association between serological status and probability of progression to clinical visceral leishmaniasis in prospective cohort studies in India and Nepal. PLoS Negl Trop Dis. 2014;8(1):e2657.

106. Ostyn B, Gidwani K, Khanal B, Picado A, Chappuis F, Singh SP, et al. Incidence of symptomatic and asymptomatic Leishmania donovani infections in high-endemic foci in India and Nepal: a prospective study. PLoS Negl Trop Dis. 2011;5(10):e1284

107. Topno RK, Das VN, Ranjan A, Pandey K, Singh D, Kumar N, et al. Asymptomatic infection with visceral leishmaniasis in a disease-endemic area in bihar. India Am J Trop Med Hyg. 2010;83(3):502-6.

108. Thakur CP, Kumar M, Kumar P, Mishra BN, Pandey AK. Rationalisation of regimens of treatment of kala-azar with sodium stibogluconate in India: a randomised study. Br Med J (Clin Res Ed). 1988;296(6636):1557-61.

109. Thakur CP, Kumar M, Pandey AK. Evaluation of efficacy of longer durations of therapy of fresh cases of kala-azar with sodium stibogluconate. Indian J Med Res. 1991;93:103-10.
110. Mishra M, Singh MP, Choudhury D, Singh VP, Khan AB. Amphotericin B for second-line treatment of Indian kala-azar. Lancet. 1991;337(8746):926.

111. Mishra M, Biswas UK, Jha DN, Khan AB. Amphotericin versus pentamidine in antimony-unresponsive kala-azar. Lancet. 1992;340(8830):1256-7.

112. Thakur CP, Sinha GP, Sharma V, Pandey AK, Kumar M, Verma BB. Evaluation of amphotericin B as a first line drug in comparison to sodium stibogluconate in the treatment of fresh cases of kala-azar. Indian J Med Res. 1993;97:170-5.

113. Mishra M, Biswas UK, Jha AM, Khan AB. Amphotericin versus sodium stibogluconate in first-line treatment of Indian kala-azar. Lancet. 1994; 344(8937):1599-600.

114. Thakur CP, Sinha GP, Pandey AK, Barat D, Singh RK. Daily versus alternateday regimen of amphotericin $B$ in the treatment of kala-azar: a randomized comparison. Bull World Health Organ. 1994;72(6):931-6.

115. Thakur CP, Sinha GP, Barat D, Singh RK. Are incremental doses of amphotericin $B$ required for the treatment of visceral leishmaniasis? Ann Trop Med Parasitol. 1994;88(4):365-70.

116. Giri OP. Treatment of visceral Leishmaniasis unresponsive to pentamidine with amphotericin B. J Assoc Physicians India. 1994;42(9):688-9.

117. Giri OP, Singh AN. Experience with amphotericin B in sodium stibogluconate-unresponsive cases of visceral Leishmaniasis in north Bihar. J Assoc Physicians India. 1994;42(9):690-1.

118. Thakur CP, Sinha GP, Pandey AK. Comparison of regimens of amphotericin B deoxycholate in kala-azar. Indian J Med Res. 1996;103:259-63.

119. Thakur CP, Kumar P, Kumar N, Singh GN, Singh AK, Narain S. A randomized comparison of classical mode of administration of amphotericin B with its newer modes of administration in kala-azar. J Assoc Physicians India. 1998;46(9):779-83.

120. Thakur CP, Singh RK, Hassan SM, Kumar R, Narain S, Kumar A. Amphotericin $B$ deoxycholate treatment of visceral leishmaniasis with newer modes of administration and precautions: a study of 938 cases. Trans R Soc Trop Med Hyg. 1999;93(3):319-23.

121. Thakur CP, Narayan S. A comparative evaluation of amphotericin B and sodium antimony gluconate, as first-line drugs in the treatment of Indian visceral leishmaniasis. Ann Trop Med Parasitol. 2004;98(2):129-38.

122. Singh UK, Prasad R, Jaiswal BP, Singh PK, Thakur CP. Amphotericin B therapy in children with visceral leishmaniasis: daily vs. alternate day, a randomized trial. J Trop Pediatr. 2010;56(5):321-4.

123. Thakur CP, Pandey AK, Sinha GP, Roy S, Behbehani K, Olliaro P. Comparison of three treatment regimens with liposomal amphotericin B (AmBisome) for visceral leishmaniasis in India: a randomized dose-finding study. Trans $\mathrm{R}$ Soc Trop Med Hyg. 1996;90(3):319-22.

124. Sundar S, Jha TK, Thakur CP, Mishra M, Singh VR, Buffels R. Low-dose liposomal amphotericin B in refractory Indian visceral leishmaniasis: a multicenter study. Am J Trop Med Hyg. 2002;66(2):143-6.

125. Sundar S, Mehta H, Suresh AV, Singh SP, Rai M, Murray HW. Amphotericin B treatment for Indian visceral leishmaniasis: conventional versus lipid formulations. Clin Infect Dis. 2004;38(3):377-83.

126. Sinha PK, Roddy P, Palma PP, Kociejowski A, Lima MA, Rabi Das VN, et al. Effectiveness and safety of liposomal amphotericin B for visceral leishmaniasis under routine program conditions in Bihar, India. Am J Trop Med Hyg. 2010;83(2):357-64

127. Thakur CP. Epidemiological, clinical and therapeutic features of Bihar kalaazar (including post kala-azar dermal leishmaniasis). Trans R Soc Trop Med Hyg. 1984;78(3):391-8.

128. Thakur CP, Kumar M, Pandey AK. Comparison of regimes of treatment of antimony-resistant kala-azar patients: a randomized study. Am J Trop Med Hyg. 1991;45(4):435-41.

129. Das VN, Siddiqui NA, Pandey K, Singh VP, Topno RK, Singh D, et al. A controlled, randomized nonblinded clinical trial to assess the efficacy of amphotericin B deoxycholate as compared to pentamidine for the treatment of antimony unresponsive visceral leishmaniasis cases in Bihar, India. Ther Clin Risk Manag. 2009;5(1):117-24.

130. Jha TK, Olliaro P, Thakur CP, Kanyok TP, Singhania BL, Singh IJ, et al. Randomised controlled trial of aminosidine (paromomycin) $\vee$ sodium stibogluconate for treating visceral leishmaniasis in North Bihar. India BMJ. 1998;316(7139):1200-5.

131. Sundar S, Agrawal N, Arora R, Agarwal D, Rai M, Chakravarty J. Short-course paromomycin treatment of visceral leishmaniasis in India: 14-day vs 21-day treatment. Clin Infect Dis. 2009;49(6):914-8.

132. Sinha PK, Jha TK, Thakur CP, Nath D, Mukherjee S, Aditya AK, et al. Phase 4 pharmacovigilance trial of paromomycin injection for the treatment of visceral leishmaniasis in India. J Trop Med. 2011;2011:645203. 
133. Sundar S, Rosenkaimer F, Makharia MK, Goyal AK, Mandal AK, Voss A, et al. Trial of oral miltefosine for visceral leishmaniasis. Lancet. 1998;352(9143):1821-3.

134. Jha TK, Sundar S, Thakur CP, Bachmann P, Karbwang J, Fischer C, et al. Miltefosine, an oral agent, for the treatment of Indian visceral leishmaniasis. N Engl J Med. 1999;341(24):1795-800.

135. Sundar S, Gupta LB, Makharia MK, Singh MK, Voss A, Rosenkaimer F, et al. Oral treatment of visceral leishmaniasis with miltefosine. Ann Trop Med Parasitol. 1999;93(6):589-97.

136. Sundar S, Makharia A, More DK, Agrawal G, Voss A, Fischer C, et al. Shortcourse of oral miltefosine for treatment of visceral leishmaniasis. Clin Infect Dis. 2000;31(4):1110-3.

137. Sundar S, Jha TK, Sindermann H, Junge K, Bachmann P, Berman J. Oral miltefosine treatment in children with mild to moderate Indian visceral leishmaniasis. Pediatr Infect Dis J. 2003;22(5):434-8.

138. Bhattacharya SK, Jha TK, Sundar S, Thakur CP, Engel J, Sindermann H, et al. Efficacy and tolerability of miltefosine for childhood visceral leishmaniasis in India. Clin Infect Dis. 2004;38(2):217-21.

139. Singh UK, Prasad R, Mishra OP, Jayswal BP. Miltefosine in children with visceral leishmaniasis: a prospective, multicentric, cross-sectional study. Indian J Pediatr. 2006;73(12):1077-80

140. Bhattacharya SK, Sinha PK, Sundar S, Thakur CP, Jha TK, Pandey K, et al. Phase 4 trial of miltefosine for the treatment of Indian visceral leishmaniasis. J Infect Dis. 2007;196(4):591-8.

141. Thakur CP, Kanyok TP, Pandey AK, Sinha GP, Messick C, Olliaro P. Treatment of visceral leishmaniasis with injectable paromomycin (aminosidine). An open-label randomized phase-II clinical study. Trans R Soc Trop Med Hyg. 2000;94(4):432-3.

142. Sundar S, Rai M, Chakravarty J, Agarwal D, Agrawal N, Vaillant M, et al. New treatment approach in Indian visceral leishmaniasis: single-dose liposomal amphotericin B followed by short-course oral miltefosine. Clin Infect Dis. 2008:47(8):1000-6

143. Sundar S, Sinha PK, Verma DK, Kumar N, Alam S, Pandey K, et al. Ambisome plus miltefosine for Indian patients with kala-azar. Trans R Soc Trop Med Hyg. 2010;105(2):115-7.

144. Sundar S, Sinha PK, Rai M, Verma DK, Nawin K, Alam S, et al. Comparison of short-course multidrug treatment with standard therapy for visceral leishmaniasis in India: an open-label, non-inferiority, randomised controlled trial. Lancet. 2011;377(9764):477-86.

\section{Submit your next manuscript to BioMed Central and we will help you at every step:}

- We accept pre-submission inquiries

- Our selector tool helps you to find the most relevant journal

- We provide round the clock customer support

- Convenient online submission

- Thorough peer review

- Inclusion in PubMed and all major indexing services

- Maximum visibility for your research

Submit your manuscript at www.biomedcentral.com/submit

) Biomed Central 